\title{
Assessing impacts of climate change, sea level rise, and drainage canals on saltwater intrusion to coastal aquifer
}

\author{
P. Rasmussen ${ }^{1}$, T. O. Sonnenborg ${ }^{1}$, G. Goncear ${ }^{2}$, and K. Hinsby ${ }^{1}$ \\ ${ }^{1}$ Geological Survey of Denmark and Greenland, GEUS, Copenhagen, Denmark \\ ${ }^{2}$ Danish Nature Agency, Roskilde, Denmark \\ Correspondence to: K. Hinsby (khi@geus.dk) \\ Received: 4 June 2012 - Published in Hydrol. Earth Syst. Sci. Discuss.: 2 July 2012 \\ Revised: 7 January 2013 - Accepted: 17 January 2013 - Published: 31 January 2013
}

\begin{abstract}
Groundwater abstraction from coastal aquifers is vulnerable to climate change and sea level rise because both may potentially impact saltwater intrusion and hence groundwater quality depending on the hydrogeological setting. In the present study the impacts of sea level rise and changes in groundwater recharge are quantified for an island located in the Western Baltic Sea. The low-lying central area of the investigated part of the island was extensively drained and reclaimed during the second half of the 19th century by a system of artificial drainage canals that significantly affects the flow dynamics of the area. The drinking water, mainly for summer cottages, is abstracted from 11 wells drilled to a depth of around $20 \mathrm{~m}$ into the upper $5-10 \mathrm{~m}$ of a confined chalk aquifer, and the total pumping is only $5-6 \%$ of the drainage pumping. Increasing chloride concentrations have been observed in several abstraction wells and in some cases the WHO drinking water standard has been exceeded. Using the modeling package MODFLOW/MT3D/SEAWAT the historical, present and future freshwater-sea water distribution is simulated. The model is calibrated against hydraulic head observations and validated against geochemical and geophysical data from new investigation wells, including borehole logs, and from an airborne transient electromagnetic survey. The impact of climate changes on saltwater intrusion is found to be sensitive to the boundary conditions of the investigated system. For the flux-controlled aquifer to the west of the drained area only changes in groundwater recharge impacts the freshwater-sea water interface whereas sea level rise does not result in increasing sea water intrusion. However, on the barrier islands to the east of the reclaimed area, below which the sea is hydraulically connected to the drainage canals, and the boundary of the flow
\end{abstract}

system therefore controlled, the projected changes in sea level, groundwater recharge and stage of the drainage canals all have significant impacts on saltwater intrusion and the chloride concentrations found in abstraction wells.

\section{Introduction}

Climate change impacts especially sea level rise and changed precipitation will challenge the current water supply management and groundwater abstraction from well fields close to the coast, globally.

Previous studies of seawater intrusion (SWI) and saltwater distribution in coastal aquifers have focused on mapping saltwater occurrence, fluid-density aspects of numerical flow modeling, effects of drainage in a polder context, effects of autonomous salinization, tidal effects, and parameter estimation (Essink, 2001; Post, 2005; Carrera et al., 2010; de Louw et al., 2011; Tran et al., 2012). More recently studies have focused on using geophysical data and groundwater age data for corroboration of SWI models (Goes et al., 2009; Vandenbohede et al., 2011; Kirkegaaard et al., 2011), as SWI models may be significantly improved by the use of efficient geophysical measurements, e.g. airborne electro-magnetics (AEM) (Comte and Banton, 2007; Comte et al., 2010; Carrera et al., 2010; Faneca Sànchez et al., 2012). Presently, focus is very much on climate change effects on seawater intrusion and saltwater distribution in coastal aquifers (Werner and Simmons, 2009; Essink et al., 2010; Webb and Howard, 2011; Chang et al., 2011).

In addition to sea level rise, most climate models predict an increase in winter precipitation for the Danish area. 
An increased winter precipitation will most likely increase groundwater recharge (van Roosmalen et al., 2007), which is expected to counteract the effect of sea level rise. Studies of the effects of sea level rise, changed recharge, and drainage elevations on seawater intrusion to coastal aquifers are described by Feseker (2007), Vandenbohede et al. (2008), Essink et al. (2010), and Sulzbacher et al. (2012). Chang et al. (2011) investigated the impact of sea level rise on an idealized coastal aquifer system and showed that for confined systems where the ambient recharge to the aquifer remains constant, sea level rise has no long-term impact on the saltwater wedge. The groundwater level is found to increase in response to sea level rise and potential intrusion effects are therefore mitigated. Werner and Simmons (2009) further show that the inland boundary conditions are crucial for the effect of sea level rise on the evolution of the saltwater wedge of unconfined aquifers. For constant flux conditions similar to those used by Chang et al. (2011), where the discharge through the aquifer is assumed to be the same with and without sea level rise, only small changes in the location of the wedge is found for typical aquifer characteristics. However, for head-controlled systems where the inland hydraulic head remains unchanged during sea level changes, the saltwater wedge is predicted to migrate hundreds of meters to several kilometers inland for realistic sea level rise and hydrogeological conditions. Study areas where the water table is controlled by drainage systems are therefore expected to be more vulnerable to future changes in sea level than natural systems.

The objectives of this study are to investigate the following questions: (a) what is the effect of climate change, including sea level rise and changed groundwater recharge, on an aquifer where the groundwater head is partly controlled by drainage canals? (b) What are the most important factors for seawater intrusion to a coastal aquifer; sea level rise, changes in groundwater recharge or water level in the drainage canals? (c) What are the dynamics of increased seawater intrusion in combination with increased recharge? (d) Will the water works have to move some of their wells in the area in the 21st century due to salinization unless measures are taken to control seawater intrusion?

The importance and effect of drainage canals is analyzed through selected climate scenarios and canal stage scenarios. The climate change impacts on the aquifer as such and on the water supply wells are analyzed. Dynamics and time lags are analyzed in a real-world confined aquifer system. Hydrochemical data, groundwater age data, airborne geophysics, and borehole logging are all used to corroborate the results from the established SWI model.

\section{Description of study area}

The study area is located in the southern part of the island of Falster in southeastern part of Denmark (Fig. 1). To the
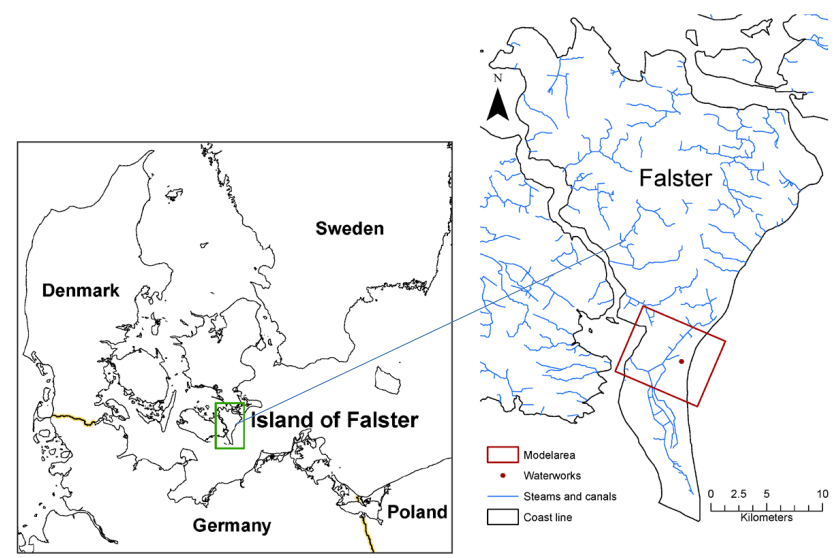

Fig. 1. Location of study area in the western Baltic Sea.

east the area is confined by the Baltic Sea and to the west by the strait of Guldborgsund. The elevation varies from $19 \mathrm{~m}$ a.s.l. (above sea level) to $-7 \mathrm{~m}$ a.s.l. to the east of the model area. The landscape is mainly developed from northsouth trending push moraine hills of clayey tills along the coast in the western part of the island (Fig. 2), which were formed during the last glaciation by an east to west moving glacier. During the Holocene, small barrier islands with eolian sand dunes, which constitute the eastern part of the island, and a lagoon developed in front of the glacial moraine hills. As the barrier islands grew it became possible to reclaim the low-lying wetland area between the push moraine and the barrier islands in the central part of the study area (Fig. 2). In the early 18th century only a small strait to the south made a connection between the shallow lagoon (Bøtø Nor) and the Baltic Sea. In the period 1860-1865 the strait was closed by a dike and the drainage of Bøtø Nor started. In 1871 a pumping station was established and after a major storm in 1872 a 17-km-long dike was built and the area was drained and converted into farm land. The pumping station is pumping water from the developed artificial drainage system to the Marrebæk canal discharging to the strait of Guldborgsund at the western coastline (Fig. 2b). The reclaimed low-lying area is dominated by marine postglacial (Holocene) sands deposited on top of a clayey ground moraine (Fig. 3).

The land use in the study area is dominated by agriculture and settlements of summer cottages, although a few small permanent villages have developed on top of the push moraine hills in the western part of the area. The first summer cottages were built in "Marielyst" in 1908 in the central part of the barrier islands along the eastern coastline close to the present location of the Marielyst Waterworks. Around 1940 more than 500 houses existed in the area. In the 1960s and 1970s the construction of houses exploded and today there are more than 5000 summer cottages. Although most of these are built on the original barrier islands in the eastern part of the investigated area, the most recent have spread into the 


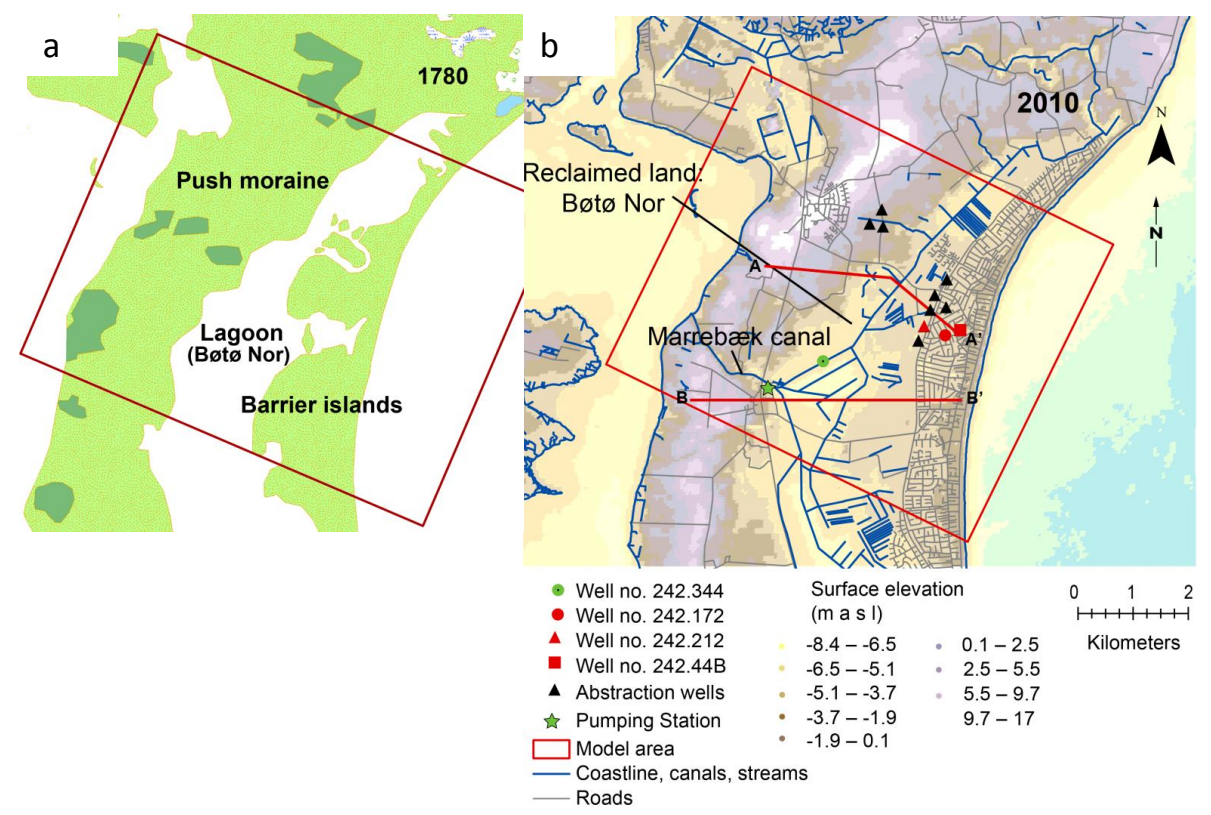

Fig. 2. Illustration of the development of the study area between 1780 and 2010 . The drainage of the lagoon was initiated in 1860 . The red lines $\mathrm{A}-\mathrm{A}^{\prime}$ and $\mathrm{B}-\mathrm{B}^{\prime}$ indicate the locations of the cross sections shown in Fig. 3. Well no. 242.44B is located at Marielyst Waterworks. Marielyst is the summer residence area along the eastern coastline.
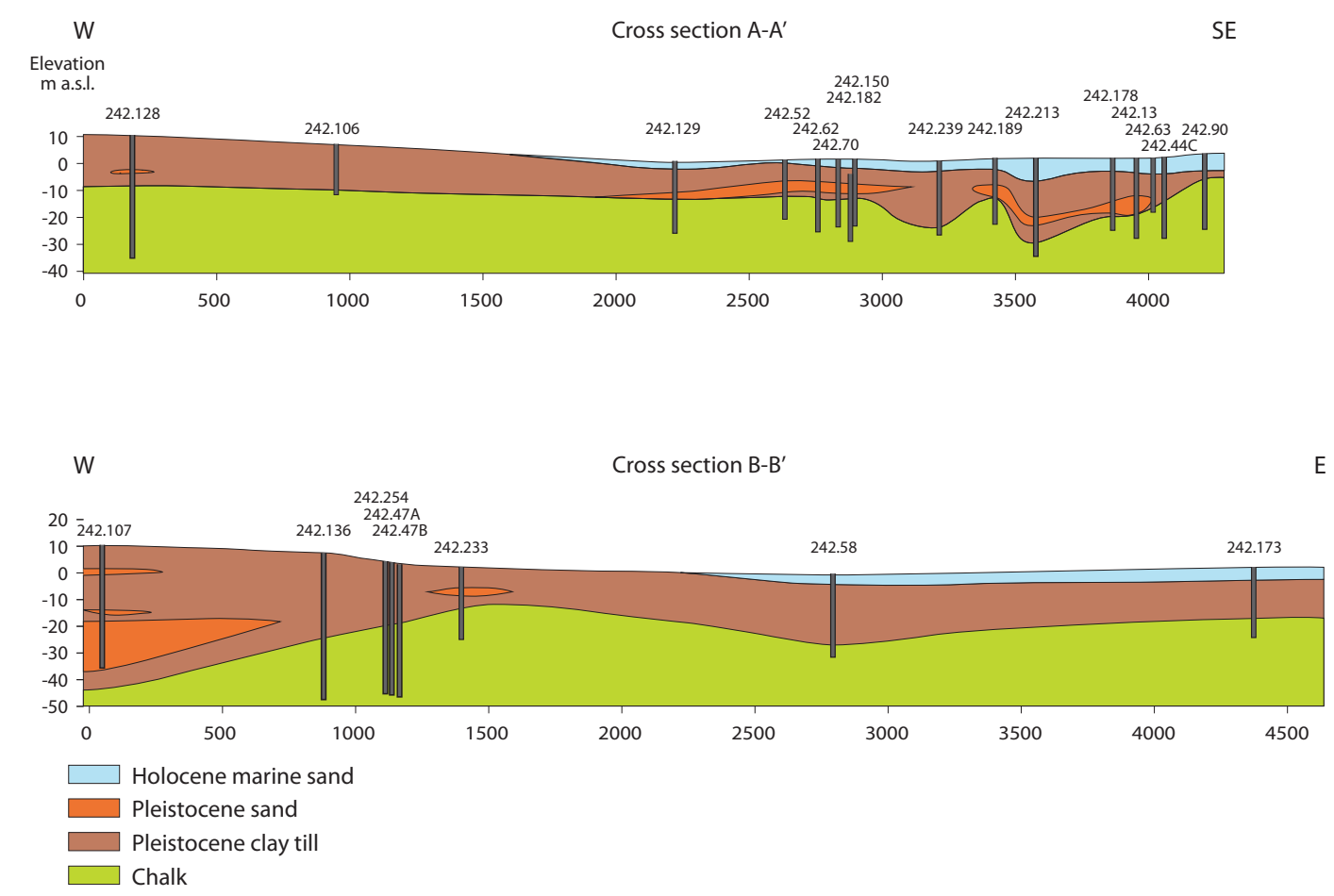

Fig. 3. Cross sections through the area showing the main geological layers, aquifers and aquitards in the established seawater intrusion (SWI) model.

reclaimed areas and some of these are therefore located at or below sea level. As estimated from the seasonal variation in abstraction, $10-15 \%$ of the houses are now used as yearround residence. The freshwater supply for the village and the summer cottages is based solely on groundwater. In this study we focus on the evolution of the salt (chloride) contents of the 11 water abstraction wells of Marielyst Waterworks supplying the summer cottages as the salinity of these are increasing (Fig. 4) and some have already been taken out of production. 
As described above, part of the area has undergone significant changes during the last centuries, from a brackish lagoon connected to the Baltic Sea to a lake, and finally to drained and reclaimed land mainly used for agriculture. The salinization effects of these changes have been included in the study by modeling four consecutive hydrographical phases leading up to the present situation. The results from these model simulations are subsequently used as a basis for simulating the impacts of climate change and sea level rise in the model area for different scenarios in two future time slices: (1) the present day to anno 2100 and (2) from 2100 to 2300 (Fig. 5)

\subsection{Geology and hydrogeology}

The geology down to $30 \mathrm{~m}$ below ground surface is quite well described with geological information from more than 70 boreholes in the area. However, only four wells are deeper than $50 \mathrm{~m}$ and no well is deeper than $100 \mathrm{~m}$, hence the information on the deeper parts of the aquifers is limited. Information on off-shore geology is scarce. A marine raw materials mapping indicates that from the shore line and 1 to $2 \mathrm{~km}$ to the east the bottom sediments consist of fine- to mediumgrained sand, whereas further to the east the bottom sediments are clayey till (Kuijpers, 1991). The Quaternary sediments consist mainly of clayey tills with local sand lenses. The thicknesses of the Quaternary deposits are up to $45 \mathrm{~m}$ in the center and southwest of the area, and down to $5-10 \mathrm{~m}$ below the post-glacial sands (Fig. 3). The post-glacial marine sands and the eolian dunes may be up to $10 \mathrm{~m}$ thick. The prequaternary Maastrichtian chalk below the Quaternary (Pleistocene) sand and clay tills (Fig. 3) continue to a depth of several hundred meters.

The main aquifer for water supply in the area is the upper chalk. The Quaternary glaciations have caused fracturing of the upper $20-30 \mathrm{~m}$ of the chalk. In this part the chalk is fully or partly refreshed due to fast advective groundwater flow through the fractures. Previous studies of chalk aquifers in Denmark have shown that the residual saltwater typically is completely flushed out in the upper $50-80 \mathrm{~m}$ of the chalk by infiltrating freshwater (Bonnesen et al., 2009). Below this zone a mixing zone with elevated chloride concentrations is seen, where the number of fractures and the effective hydraulic conductivity is gradually decreasing compared to the fully refreshed zone above. Below this depth matrix diffusion is the dominating transport process for saltwater (Bonnesen et al., 2009). At depth below $150-200 \mathrm{~m}$ the saltwater is of oceanic concentration with total dissolved solids (TDS) concentrations above $35000 \mathrm{mg} \mathrm{L}^{-1}$ and chloride concentrations above $19000 \mathrm{mg} \mathrm{L}^{-1}$.

\subsection{Hydrology}

The average annual precipitation in the area is approximately $700 \mathrm{~mm}$. Based on results from the national water resources model, The DK-Model (Henriksen et al., 2003, 2008;

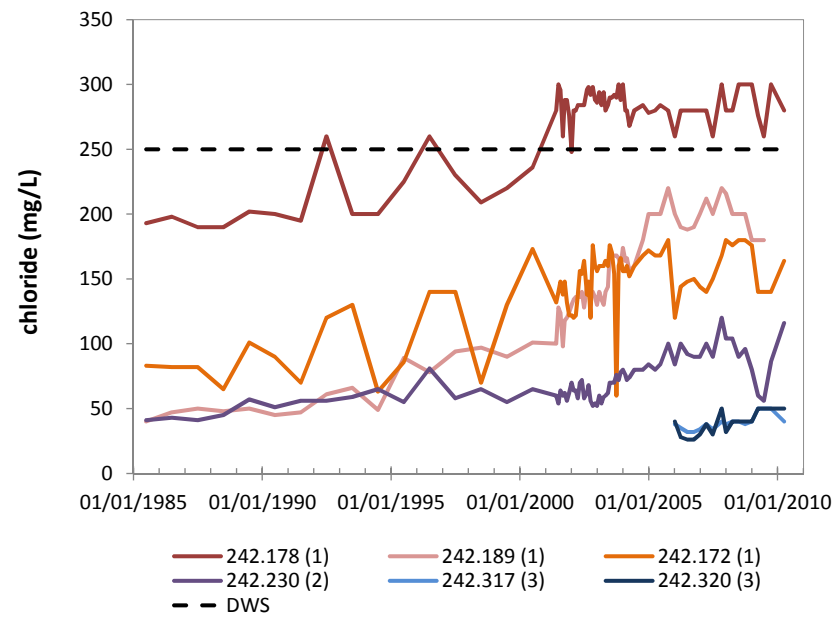

Fig. 4. The development of chloride concentrations in water supply wells. The chloride concentrations have been analyzed approximately once a year since 1985. Selected examples from all three well fields (Fig. 6) are shown. DWS: The EU/WHO drinking water standard for chloride $\left(=250 \mathrm{mg} \mathrm{L}^{-1}\right)$.

Højberg et al., 2008), groundwater recharge has been estimated on a daily basis for the period 1990-2010. For the present study area the annual variation in the period was $79-437 \mathrm{~mm} \mathrm{yr}^{-1}$. The surface water system is dominated by the artificial drainage canal system. A few minor creeks flow towards the drainage system or towards Guldborgsund. The drainage system is lowering the water table in the area where the ground surface has elevations between +1 and $-3 \mathrm{~m}$ a.s.l. The pumping station is aiming at keeping a constant water level in the drainage canals. During a field campaign the water level in the drainage system was measured at several locations across the drained area and the stages were found to vary between -1 and $-2.5 \mathrm{~m}$ a.s.l.

The Marielyst Waterworks supplies water to 5200 households. Due to the high percentage of summer cottages in the area, the groundwater supply varies considerably during the year with a maximum of $2000 \mathrm{~m}^{3}$ day $^{-1}$ in July to a minimum of $300 \mathrm{~m}^{3}$ day $^{-1}$ in January. The waterworks has 11 active abstraction wells, which are located in three separate well fields (Figs. 2 and 6). The oldest well field is located about $0.5 \mathrm{~km}$ from the coast, a second group of wells are approximately $1 \mathrm{~km}$ from the coast (established 1975-1990) and both well fields are located on one of the former barrier islands. The newest well field is located in the central part of the island $2.5 \mathrm{~km}$ from the coast lines, and were established in 2005 in or very close to the main groundwater recharge area in the push moraine hills. Individual pumping rates or pumping schemes for each well were not available for this study. All 11 water abstraction wells of Marielyst Waterworks are drilled to a depth of 10-15 $\mathrm{m}$ into the upper fractured chalk aquifer (Jupiter, 2011). Significant groundwater abstraction has taken place since the 1960s. The annual groundwater 


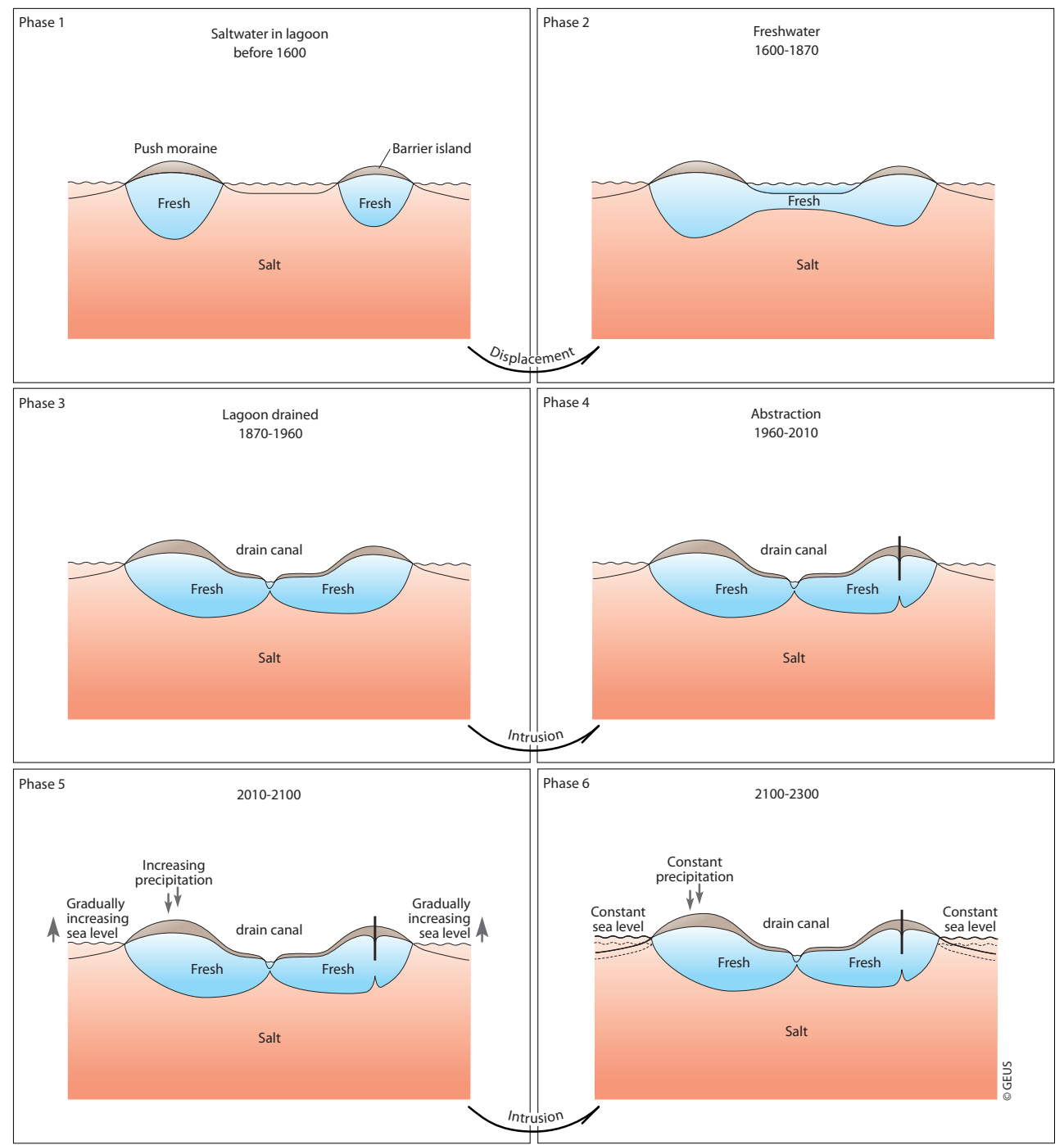

Fig. 5. Modeled transition phases of study area from lagoon with barrier islands to reclaimed land with groundwater abstraction and climate change impacts. Model results of previous phase define initial conditions of subsequent phase.

production reached its maximum around $470000 \mathrm{~m}^{3} \mathrm{yr}^{-1}$ in the beginning of the 1980s and has since then decreased to the present level of around $250000 \mathrm{~m}^{3} \mathrm{yr}^{-1}$, mainly due to repair of leaky water pipes.

Additionally, groundwater abstraction takes place from two other minor waterworks and a few irrigation wells, which add up to approximately $150000 \mathrm{~m}^{3} \mathrm{yr}^{-1}$. The total groundwater abstraction in the model area is around $0.4 \times 10^{6} \mathrm{~m}^{3} \mathrm{yr}^{-1}$. The pumping station is pumping $6.5 \times 10^{6} \mathrm{~m}^{3} \mathrm{yr}^{-1}$ from the area to the Guldborgsund strait via the Marrebæk canal including approximately $0.7 \times 10^{6} \mathrm{~m}^{3} \mathrm{yr}^{-1}$ of treated sewage water, which has been discharged to the canal from a wastewater treatment plant. The mean groundwater recharge for the model area is $8460000 \mathrm{~m}^{3} \mathrm{yr}^{-1}$, where the total groundwater abstraction is $400000 \mathrm{~m}^{3} \mathrm{yr}^{-1}$ or $4.7 \%$ of the recharge.
The tidal amplitude in the area is relatively small, less than $0.2 \mathrm{~m}$, therefore tidal effects have been ignored in this study.

\subsection{Groundwater chemistry in water supply wells}

As described in the previous section the water supply wells of Marielyst Waterworks has 11 wells grouped in three well fields at different distances to the sea (well field 1-3; Fig. 6). Only 10 wells are currently active, as one of the wells in well field 1 has been taken out of production. General groundwater chemistry of major ions have been analysed approximately once a year in all water supply wells since 1985 (since 2006 in the newest well field). During this period all wells show steadily increasing chloride concentrations (Fig. 4). Only one well (242.178) in well field 1 closest to the sea is still active, although it has concentrations above the WHO/EU drinking water standard of $250 \mathrm{mg} \mathrm{L}^{-1}$. Another 


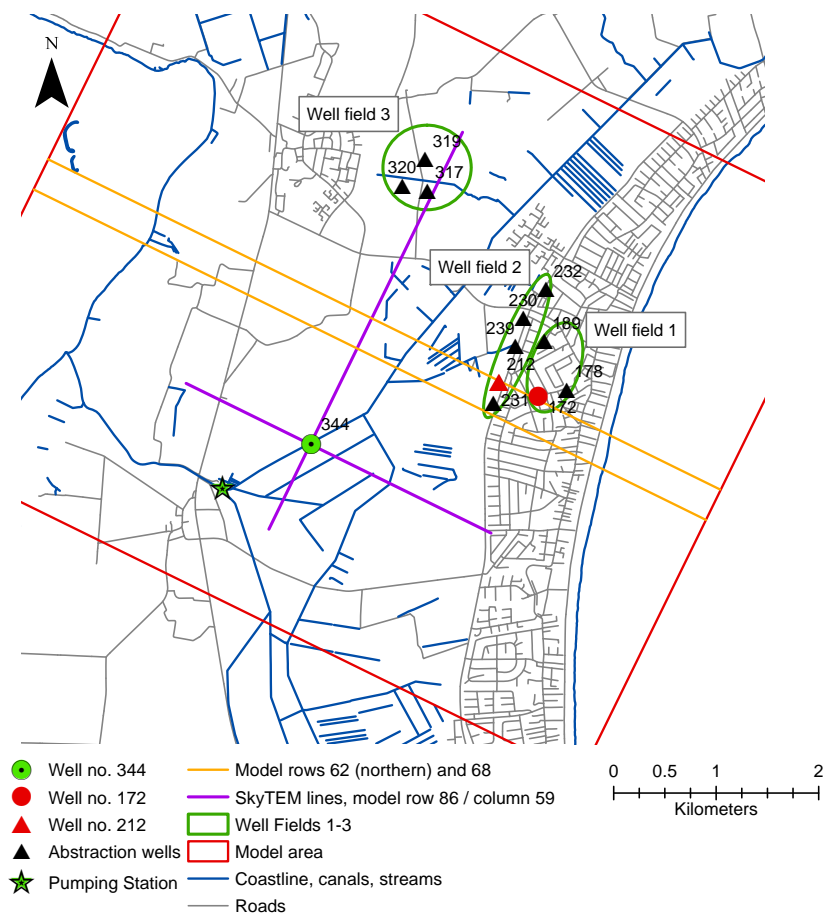

Fig. 6. Model area with groundwater abstraction wells and new 100m-deep monitoring well 344. Model rows, locations of well 212 and 172, and SkyTEM-profiles shown are used for illustration of model validation and results. Note that well numbers are indicated without the prefix " 242 ." used elsewhere in text and figures.

well (242.44 B), located at the waterworks, has chloride analyses from $1970\left(148 \mathrm{mg} \mathrm{L}^{-1}\right)$ until $2004\left(293 \mathrm{mg} \mathrm{L}^{-1}\right)$ when the well was taken out of production due to elevated chloride concentrations above the drinking water standard. Well field 3 was established at approximately the same time to support increasing demands and ensure the supply for all consumers. In addition to the general geochemistry of major ions, all wells were analysed every 3-4 yr for contaminants such as organic micro-contaminants, pesticides, and nitrate, as described in the Danish monitoring programme. Generally, there are no traces of contaminants or human impacts on the extracted groundwater, indicating that the groundwater pumped for water supply recharged the chalk aquifer prior to 1950 (e.g. Hinsby et al., 2001).

\section{Data collection and conducted investigations}

\subsection{Groundwater chemistry and environmental tracers}

Groundwater samples were collected from selected water supply wells in collaboration between GEUS and the waterworks for the analysis of general hydrochemistry and groundwater age estimation by the environmental tracers ${ }^{3} \mathrm{H} /{ }^{3} \mathrm{He}$.
Major ion analyses were performed in the laboratory at GEUS by atom absorption spectroscopy (Ca), ion chromatography ( $\mathrm{Na}, \mathrm{K}, \mathrm{Mg}, \mathrm{Cl}, \mathrm{Br}, \mathrm{F}, \mathrm{SO}_{4}^{2-}$ ), FIA/Flow Injection Analysis $\left(\mathrm{NH}_{4}^{+}\right)$and spectroscopy $\left(\mathrm{PO}_{4}^{3-}\right)$. Alkalinity was measured in the field by Gran titration, while $\mathrm{O}_{2}, \mathrm{pH}$ and SEC (specific electrical conductivity) were measured by standard WTW electrodes in the field. The total dissolved solids were calculated manually from the analysis of the major cations and anions, after checking of the ion balance for every sample.

\section{${ }^{3} \mathrm{H}^{3} \mathrm{He}$}

Samples for ${ }^{3} \mathrm{H},{ }^{3} \mathrm{He}$ isotope analysis and groundwater dating were collected in two copper tubes (for noble gases) and a $1 \mathrm{~L}$ plastic bottle (for ${ }^{3} \mathrm{H}$ ) by sampling techniques provided by the "Helis-Helium Isotope Studies Bremen" (University of Bremen), where the collected samples were analysed by mass spectrometry and interpreted in terms of groundwater age (Sueltenfuss et al., 2009, 2011). Tritium $\left({ }^{3} \mathrm{H}\right)$ is determined by the helium-in-growth method where the decay product of ${ }^{3} \mathrm{H}\left({ }^{3} \mathrm{He}\right)$ is measured by mass spectrometry (Sueltenfuss et al., 2009) with a detection limit of $0.01 \mathrm{TU}$ $\left(1 \mathrm{TU}={ }^{3} \mathrm{H} /{ }^{2} \mathrm{H}\right.$ ratio of $\left.1 \times 10^{-18}\right)$.

\subsection{Airborne geophysics and borehole logging}

Borehole logging (Buckley et al., 2001) and airborne electromagnetics (AEM) by the SkyTEM method (Sørensen and Auken, 2004) have proven their value for the mapping of fresh and saltwater distribution in the subsurface in Danish geological settings (Buckley et al., 2001; Kirkegaard et al., 2011; Jørgensen et al., 2012). We therefore used these methods to provide valuable data on salinity variations in the subsurface for the model setup and for corroboration of the simulation results in the investigated area. The geophysical investigations were conducted as part of the study mainly to supplement the existing knowledge of the lithological variations (distribution of aquitards and aquifers), groundwater flow in aquifers, and the subsurface distribution of saltwater.

\section{Borehole logging}

Borehole wireline geophysics were conducted by GEUS in 14 wells, including three new wells drilled during the project, primarily to evaluate the fresh/saltwater boundaries. The logging program was conducted using standard slimhole logging equipment (by Robertson Geologging LTD). The collected data are used to evaluate geological stratification, saltwater distribution and groundwater flow into wells (e.g. Buckley et al., 2001; Maurer et al., 2009), and to support and corroborate the interpretation of the regional airborne SkyTEM measurements (Jørgensen et al., 2012). The combined use of logging probes measuring natural gamma radiation, formation conductivity (focused induction $\log$ ), fluid conductivity and temperature, and inflow to wells (propeller 
Table 1. Model phases (illustrated in Fig. 5).

\begin{tabular}{lrrrl}
\hline Phase & $\begin{array}{c}\text { Start } \\
\text { year }\end{array}$ & $\begin{array}{l}\text { End } \\
\text { year }\end{array}$ & Years & \\
\hline 1 & & & 3000 & Lagoon open to Baltic Sea, saltwater in lagoon \\
2 & 1601 & 1870 & 270 & Minor outlet from lagoon to Baltic Sea, freshwater in lagoon \\
3 & 1871 & 1960 & 90 & Reclamation and drainage of lagoon \\
4 & 1961 & 2010 & 50 & Groundwater abstraction \\
5 & 2011 & 2100 & 90 & Climate change effects implemented \\
6 & 2101 & 2300 & 200 & Climate change input held constant \\
\hline
\end{tabular}

flow meter) were applied to, e.g. identify whether low formation resistivities are due to saline porewaters or high clay contents in sediments (Faneca Sànchez et al., 2012), and to identify hydraulically active zones in the chalk aquifer.

\section{AEM (SkyTEM)}

An airborne (helicopter) time domain electromagnetic survey (SkyTEM, Sørensen and Auken, 2004) was flown over areas covering most of well field 2 and 3 . The SkyTEM system was developed for high-resolution surveys especially for hydrogeological investigations. In this particular SkyTEM survey an average helicopter speed of $13 \mathrm{~m} \mathrm{~s}^{-1}$ was chosen and the transmitter ( $314 \mathrm{~m}^{2}$ octagonal loop) set up with a low moment $\left(10 \mathrm{~A} \times 314 \mathrm{~m}^{2} \times 1\right.$ turn $\left.=3140 \mathrm{Am}^{2}\right)$ and a high moment $\left(100 \mathrm{~A} \times 314 \mathrm{~m}^{2}\right) \times 2$ turns $=62800 \mathrm{Am}^{2}$, enabling shallow and deep penetration, respectively, and allowing TEM measurements every $30 \mathrm{~m}$ with a depth of investigation of up to 120-150 m (Auken et al., 2009a). The survey provides resistivity or electrical conductivity maps of the subsurface indicating, e.g. the distribution of saltwater in aquifers (Auken et al., 2009b; Kirkegaard et al., 2011; Jørgensen et al., 2012). Approximately $50 \mathrm{~km}$ of SkyTEM were flown in the investigated area with a distance between flightlines of 150-200 m. The data was processed and inverted with Spatially Constrained Inversion algorithm (Viezzoli et al., 2008), using the Aarhus Workbench software (Auken et al., 2009b; Aarhus Geophysics, 2009). Unfortunately, due to a large number of electrical cables, it was not possible to measure in the housing areas along the eastern coastline and around well field 1.

\subsection{Flow and transport model}

The numerical modeling complex MODFLOW-2000/ MT3DMS/SEAWAT was used for simulating 3-D variable density groundwater flow and solute transport (Harbaugh et al., 2000; Zheng and Wang, 1999; Zheng, 2010; Langevin et al., 2007). The user interface Groundwater Vistas version 6 was used as the pre- and post-processing tool (Rumbaugh and Rumbaugh, 2011).

The groundwater abstraction, the groundwater recharge, and the drainage canals are simulated with the MODFLOW
Well Package, the Recharge Package, and the Drainage Package. The Time-Variant Specified-Head (CHD) package is used to assign specified or constant head boundaries that can change within or between stress periods (Harbaugh et al., 2000). When using the CHD package for variably density, modeling the reference head value assigned to the boundary cell is updated prior to each transport time step using the fluid density from the previous transport time step. By this procedure the head value used for each transport time step is referenced to the calculated density value at that cell (Langevin et al., 2007).

The Hydrogeologic-Unit Flow (HUF) Package was used for the MODFLOW-2000 program (Anderman and Hill, 2000). The HUF package is a flow-package that makes it possible to define hydrogeological units that are independent from the numerical layers. Hydraulic properties are assigned to the hydrogeological units in the HUF package and the HUF package calculates the effective hydraulic properties for the numerical layers. The advantage of using the HUF package in variable density modeling is the ability to represent hydrological units of variable thickness and distribution, while still honoring the recommendations of using horizontal numerical layers of uniform thickness for density modeling (Langevin et al., 2007).

The Preconditioned Conjugate-Gradient (PCG2) Package is used to solve the flow equations.

Due to the length of simulation time the Finite Difference solution scheme is used for solving the advection term of the solute transport equation in the first three modeling phases, despite the risk of numerical dispersion. For the three last model phases including the scenario, simulations the TVD method is used. The TVD method introduces only limited numerical dispersion. The Generalized Conjugate Gradient solver (GCG) with the SSOR pre-conditioner is used for solving the sink/source and dispersion terms.

A sensitivity analysis is performed comparing the use of the Finite Difference solution scheme compared to the TVD solution scheme on the effect on salinity in groundwater abstraction wells.

For SEAWAT_V4 the Variable-Density Flow (VDF) package is used. The Density-Concentration slope is defined in the VDF package. 
Table 2. Climate change scenarios.

\begin{tabular}{lrrl}
\hline Scenario & SLR & Recharge & Drain stage \\
\hline 0 & $0 \mathrm{~m}$ & $0 \%$ & no change \\
1 & $0.75 \mathrm{~m}$ & $+15 \%$ & no change \\
2 & $0.75 \mathrm{~m}$ & $0 \%$ & no change \\
3 & $0.75 \mathrm{~m}$ & $-15 \%$ & no change \\
4 & $0 \mathrm{~m}$ & $+15 \%$ & no change \\
5 & $0.5 \mathrm{~m}$ & $+15 \%$ & no change \\
6 & $1 \mathrm{~m}$ & $+15 \%$ & no change \\
7 & $0.75 \mathrm{~m}$ & $+15 \%$ & $+30 \mathrm{~cm}$ \\
8 & $0.75 \mathrm{~m}$ & $+15 \%$ & $-30 \mathrm{~cm}$ \\
\hline
\end{tabular}

\subsection{Scenarios}

The central part of Falster has, as described above, undergone several significant changes in the hydrological system during the last centuries. These changes may be divided into four phases (Table 1, Fig. 5). Until around the 16th century (phase 1) we assume the lagoon was open to the Baltic Sea and the water was salt/brackish. Due to the sedimentation around the barrier islands, the outlet between the lagoon and the Baltic Sea became narrower and the water in the lagoon became fresher (phase 2). Around 1870 the connection to the sea was closed and the reclamation and drainage of the area was initiated and a pumping station built (phase 3). Later Marielyst Waterworks was established on one of the barrier islands and groundwater abstraction was initiated (phase 4). This four-phase transition from saltwater lagoon to reclaimed land with groundwater abstraction forms the initial conditions for the climate scenarios (Table 2, Fig. 5). An autonomous salinization might be ongoing, i.e. the aquifer system may not be in dynamic equilibrium with respect to salinization after these relatively recent significant changes in the hydrological system.

The scenarios focus on two aspects of climate change: sea level rise and change in groundwater recharge. The basic climate scenario includes a sea level rise of $0.75 \mathrm{~m}$ and an increase in groundwater recharge of $15 \%(36 \mathrm{~mm})$ in the period from 2010 to 2100 (phase 5). The increase in groundwater recharge is based on van Roosmalen et al. (2007), who has estimated the expected change in groundwater recharge for a comparable area in Denmark based on output from regional climate models representing IPCC scenarios A2 and B2. In phase 6 both recharge and sea level are kept constant for an additional $200 \mathrm{yr}$ to capture the long-term effects of the imposed climate changes (Fig. 5).

Eight climate change scenarios were simulated with different combinations of sea level rise, groundwater recharge, and drainage canal stage (Table 2). Scenario 0 represents a situation where no changes occur. Scenario 1 represents an estimate of the most likely future with an increase in recharge of $15 \%$ and sea level rise of $0.75 \mathrm{~m}$. In scenario 2-8 a sensitivity analysis of the most likely scenario is carried out, where other realistic changes in sea level and recharge have been implemented. The drainage canals play an important role in the modeled groundwater system. To evaluate the sensitivity of the drains two simulations (scenarios 7 and 8) are performed with changed stage, +30 and $-30 \mathrm{~cm}$, respectively.

\section{Model setup, calibration and validation}

\subsection{Hydro-stratigraphic model}

The hydrogeological model is based on the hydrostratigraphic layers defined in the DK-model (Højberg et al., 2008). The DK-model in the area is developed with eight alternating Quaternary clayey till and sand layers with Cretaceous chalk below. The surfaces and thicknesses of the model layers in the DK-Model have been estimated on the basis of the extensive national well record database with more than two wells per square kilometer (national average), geological maps and models, and regional geophysical surveys. The hydro-stratigraphic model layers are interpreted in horizontal/lateral grid of $100 \mathrm{~m} \times 100 \mathrm{~m}$.

In the study area, three adjustments of the hydrostratigraphic layers have been made. Based on the soil map and geological information from wells, a top layer of $5 \mathrm{~m}$ of sand is implemented where the soil map shows sand. Clayey till is assigned elsewhere in the top layer. The upper $5 \mathrm{~m}$ of the clayey till is assumed fractured with a higher hydraulic conductivity than the deeper lying clayey till (Højberg et al., 2008). Based on studies of comparable chalk formations in Denmark, Bonnesen et al. (2009) suggest that the upper 30 $80 \mathrm{~m}$ of the chalk is fully refreshed due to fracture systems, allowing freshwater to circulate and displace the original marine saltwater. The stratification of the upper part of the chalk aquifer may be conceptualized in three units: an upper zone crushed by glacial activities with many fractures, high effective hydraulic conductivity and dominated by advective groundwater flow; an intermediate fractured and partly refreshed mixing zone (Bonnesen et al., 2009; Larsen et al., 2006) with a medium hydraulic conductivity; and a deeper zone with low hydraulic conductivity dominated by diffusion. This development was confirmed by geophysical logs in the new investigation well 242.344, which was drilled in the project (Figs. 2 and 8).

In order to represent an upper zone where solute transport is dominated by advection and a deeper zone where solute transport is dominated by diffusion, the chalk formation has been divided into eight hydro-stratigraphic layers with gradually decreasing hydraulic conductivity. The upper four layers have a thickness of $15 \mathrm{~m}$ while the lower four layers have a thickness of $30 \mathrm{~m}$. The hydro-stratigraphic layers of the chalk formation follow the topography of the top chalk i.e. the prequaternary surface. 
Table 3. Boundary conditions for three model phases.

\begin{tabular}{lrrrllll}
\hline Phase & $\begin{array}{l}\text { Start } \\
\text { year }\end{array}$ & $\begin{array}{l}\text { End } \\
\text { year }\end{array}$ & Years & $\begin{array}{l}\text { Constant } \\
\text { Head } \\
\text { Lagoon } \\
(\mathrm{m})\end{array}$ & $\begin{array}{l}\text { Constant } \\
\text { Conc. } \\
\text { Lagoon } \\
\text { (TDS mg L }\end{array}$ & $\begin{array}{l}\text { Drain in } \\
\text { Lagoon }\end{array}$ & $\begin{array}{l}\text { Groundwater } \\
\text { abstraction }\end{array}$ \\
\hline 1 & & & 3000 & 0 & 10500 & No & No \\
2 & 1601 & 1870 & 270 & 0.2 & 0 & No & No \\
3 & 1871 & 1960 & 90 & No & No & Yes & No \\
4 & 1961 & 2010 & 50 & No & No & Yes & Yes \\
\hline
\end{tabular}

\subsection{Model setup}

The model area covers an area of $44 \mathrm{~km}^{2}$, where $12 \mathrm{~km}^{2}$ or $27 \%$ of the area is sea (Figs. 1 and 2). Horizontally, a grid size of $50 \mathrm{~m}$ by $50 \mathrm{~m}$ is used, while in the vertical 32 numerical layers with thicknesses varying from 2 to $12 \mathrm{~m}$ are specified, adding up to a total number of active cells of 560640. The thickness of the numerical layers gradually increases with depth down to $-200 \mathrm{~m}$ a.s.1. The top elevation follows the digital terrain model including the elevation of the sea floor. In order to ensure that the drainage canal is located in the top layer the bottom of the top layer is specified at $4 \mathrm{~m}$ below ground surface. A minimum of $2 \mathrm{~m}$ layer thickness means that the model layer topography has been modified in the sea area.

The boundary conditions of the model include constant head in the uppermost model layer in the area representing the sea, drains in 848 cells, no-flow along the outer boundaries, as well as groundwater recharge and groundwater abstraction. Constant head boundary is only specified in cells representing the sea and drainage canals? and only in model layer 1. Recharge was allowed in all other cells. Thus the groundwater table was allowed to move freely in the upper layer in cells not representing the sea or the drainage canal. As the focus area of the model simulations are in the central eastern part of the model area, an approximation of noflow for the northern boundary is applied. This is confirmed by simulations with the DK-model (Højberg et al., 2008). A horizontal impermeable layer at $-200 \mathrm{~m}$ depth defines the bottom of the numerical model.

The simulation of seawater intrusion has been divided into six phases (Fig. 5) using four separate but consecutive model setups and simulations with different boundary conditions to represent the historical situation (Table 3). The groundwater head and salinity distribution at the end of each model phase was used as initial heads and concentrations for the consecutive model phase. In phase one the salt concentration in the lagoon, Bøtø Nor, is assumed to be the same as the Baltic Sea, $10500 \mathrm{mg} \mathrm{L}^{-1}$, while the water level of the lagoon is assumed to be $0 \mathrm{~m}$ a.s.l. To reach a steady-state situation for the saltwater-freshwater distribution of the modeled system a $3000 \mathrm{yr}$ simulation period was performed. The lagoon area was delineated based on a map from 1780 (Fig. 2). The second model phase from 1600 to 1870 is characterized by freshwater in the lagoon and a water table $0.2 \mathrm{~m}$ above the Baltic Sea. In the third phase representing the period after 1870, where the reclamation and drainage of the old lagoon area started, the constant head in the lagoon area is replaced by a system of drainage canals. The fourth period starts in 1960, where substantial groundwater abstraction began. At this time eleven abstraction wells with constant abstraction rate are introduced to the model. Due to the post-glacial rebound in the area it is assumed that the uplift has outbalanced the sea level rise between the phases $1-4$, and it is assumed to be negligible considering other uncertainties of the hydrogeographic development during the same period.

The implementation and impact of the climate changes were modeled through an additional two model phases (Fig. 5). The effects of sea level rise and changed groundwater recharge are gradually implemented in the fifth model phase from 2010 to 2100 . At the beginning of each $10-y r$ period one-tenth of the change is applied to the model, which means that the first change is implemented in year 2010 and the last change in year 2100. For scenarios 7-9 (Table 2) the change in drain stage are implemented from the beginning of the simulation period in 1960 . For scenario 9 the groundwater head in the lagoon area follows the sea level rise. To see possible delayed effects of the climate change impacts the simulations are continued for another $200 \mathrm{yr}$ with the sea level and groundwater recharge of the sixth model phase kept constant.

The groundwater abstraction at Marielyst Waterworks is distributed evenly among the 11 wells in use for the model simulations, as information of individual abstraction rates was not available. The total average annual abstraction rate is $250000 \mathrm{~m}^{3} \mathrm{yr}^{-1}$. An average annual recharge of $242 \mathrm{~mm} \mathrm{yr}^{-1}$ was use in the model simulations.

Also a transient model is set-up with monthly values for groundwater abstraction and recharge for model calibration. Monthly variations in groundwater abstraction are specified according to Table 4. Monthly averages of recharge for the period 1990-2010 were used as input to the model. The monthly variations in groundwater recharge and 
Table 4. Estimated monthly variation in groundwater abstraction.

\begin{tabular}{lcccccccccccc}
\hline Month & Jan & Feb & Mar & Apr & May & Jun & Jul & Aug & Sep & Oct & Nov & Dec \\
\hline Distribution (\%) & 7 & 6 & 6 & 7 & 9 & 11 & 15 & 12 & 8 & 7 & 6 & 6 \\
\hline
\end{tabular}

groundwaterabstraction were simulated for the period 1 January 1991 to 31 December 2010 (240 stress periods).

\subsection{Calibration of flow model}

A sensitivity analysis performed using PEST (Doherty, 2005) showed highest sensitivities for the vertical hydraulic conductivity of the clayey till, horizontal hydraulic conductivity of the sand and the upper chalk layer, and the hydraulic conductivity near the drains. Initially, automatic parameter estimation using PEST of the hydraulic conductivities for the hydro-stratigraphic layers and drainage level was tried, but due to the uneven distribution of the head data it was not possible to come up with groundwater head distribution comparable to previous studies. So a trial and error calibration using the parameters from the DK-Model as a starting point was performed on the steady-state flow model (Sonnenborg et al., 2003).

A comparison of the calibration statistics for the steadystate model shows good agreement between the numerical model without density and the numerical model with density effects (Table 5). The minor difference in the residual error between the model simulations with and without a density model is probably due to the fact that the stage of the drainage canal is controlling the groundwater head in the barrier island area between the drainage canals and the eastern shore line, where the majority of head measurements for model calibration are also measured. Further, the salinity and hence density of the saltwater in the Baltic Sea is quite low $(\sim 1.0 \%)$ compared to oceanic concentrations, meaning that density effects are less significant. The calibration results for the groundwater heads for the steady-state models are regarded as satisfactory with a RMS value of $1.53 \mathrm{~m}$. The used groundwater heads for model calibration were all measured in boreholes with low salinity and density effects on hydraulic heads are insignificant. For the transient calibration a $R^{2}$-value (the Nash-Suthcliffe coefficient) of 0.88 was found for the drainage canal main gauging station based on monthly data, which in general is an acceptable calibration result. The best calibration of the numerical flow model was achieved to the east and north around the well field areas with respect to groundwater heads. Figure 7 shows groundwater head for model layer 7 ( -18 to $-21 \mathrm{~m}$ a.s.l.), the groundwater flow velocity vectors in a cross-section, and observed versus simulated groundwater heads. The calibration results are found satisfactory as:

1. The defined geological units are assumed to be homogeneous, which indeed is not the case in reality. The
Table 5. Calibration statistics.

\begin{tabular}{lll}
\hline & $\begin{array}{l}\text { Numerical } \\
\text { model, no } \\
\text { density }\end{array}$ & $\begin{array}{l}\text { Numerical } \\
\text { model, with } \\
\text { density }\end{array}$ \\
\hline \multicolumn{3}{c}{ Groundwater head obs. } \\
\hline $\begin{array}{l}\text { Residual mean (m) } \\
\text { RMS error (m) }\end{array}$ & -0.14 & -0.15 \\
Number of observations & 30 & 1.53 \\
\hline \multicolumn{3}{c}{ Drain canal flow } \\
\hline $\begin{array}{l}\text { Deviation from target (\%) } \\
\text { Number of observations }\end{array}$ & 13.2 & 13.5 \\
\hline
\end{tabular}

hydraulic parameters of each of the geological units are expected to exhibit heterogeneity to a certain degree, which cannot be quantified based on the available data. Especially the fractured chalk aquifers are expected to exhibit strong spatial variability in hydraulic conductivity. Hence, even though the overall flow field is described reasonably well by the model, the prediction of hydraulic head locally at the wells may not match the observed data precisely.

2. Data on groundwater abstraction is only available at the level of waterworks. Hence, no information on the abstraction from the individual abstraction wells is available and therefore the total abstraction has been distributed evenly on the wells. This translates into a significant uncertainty on the local groundwater abstraction, which in turn affects the ability of the model to accurately describe the local groundwater heads.

3. The observations of hydraulic head used for calibration are collected over a period of more than $10 \mathrm{yr}$ and may be affected by transient effects. Some data are measured during wintertime when the hydraulic head is relatively high, while others are measured during the summer season when heads are relatively low.

In conclusion we would not expect, with the uncertainties described above in mind, that the model results could be improved significantly by further calibration.

The main model parameters are shown in Table 6. Dispersivity values are based on values from previous studies on tracer transport in Danish chalk (Brettmann et al., 1993).

A sensitivity analysis was performed to evaluate the importance of the longitudinal dispersivity value and the 
Table 6. Model parameters.

\begin{tabular}{|c|c|}
\hline Parameter name & Value \\
\hline Horizontal hydraulic conductivity, sand $\left(\mathrm{m} \mathrm{s}^{-1}\right)$ & $5 \times 10^{-4}$ \\
\hline Horizontal hydraulic conductivity, clayey till, top layer $\left(\mathrm{m} \mathrm{s}^{-1}\right)$ & $5 \times 10^{-6}$ \\
\hline Horizontal hydraulic conductivity, clayey till, aquitard $\left(\mathrm{m} \mathrm{s}^{-1}\right)$ & $1 \times 10^{-6}$ \\
\hline Horizontal hydraulic conductivity, chalk, aquifer $\left(\mathrm{m} \mathrm{s}^{-1}\right)$ & $5 \times 10^{-5}$ \\
\hline Horizontal hydraulic conductivity, chalk, less fractured $\left(\mathrm{m} \mathrm{s}^{-1}\right)$ & $1 \times 10^{-5}-2 \times 10^{-8}$ \\
\hline Vertical Anisotropy $(\mathrm{Kz} / \mathrm{Kx})$ & 0.1 \\
\hline Effective porosity & $5-35$ \\
\hline Specific yield & $0.05-0.35$ \\
\hline Specific storage $\left(\mathrm{m}^{-1}\right)$ & $1 \times 10^{-4}-1 \times 10^{-5}$ \\
\hline Dispersivity, longitudinal (m) & 8 \\
\hline Dispersivity, transverse (m) & 0.05 \\
\hline Dispersivity, vertical (m) & 0.001 \\
\hline Diffusion $\left(\mathrm{m} \mathrm{s}^{-1}\right)$ & $4.1 \times 10^{-10}$ \\
\hline Baltic Sea Salinity (TDS $\left(\mathrm{g} \mathrm{L}^{-1}\right)$ & 10.5 \\
\hline
\end{tabular}

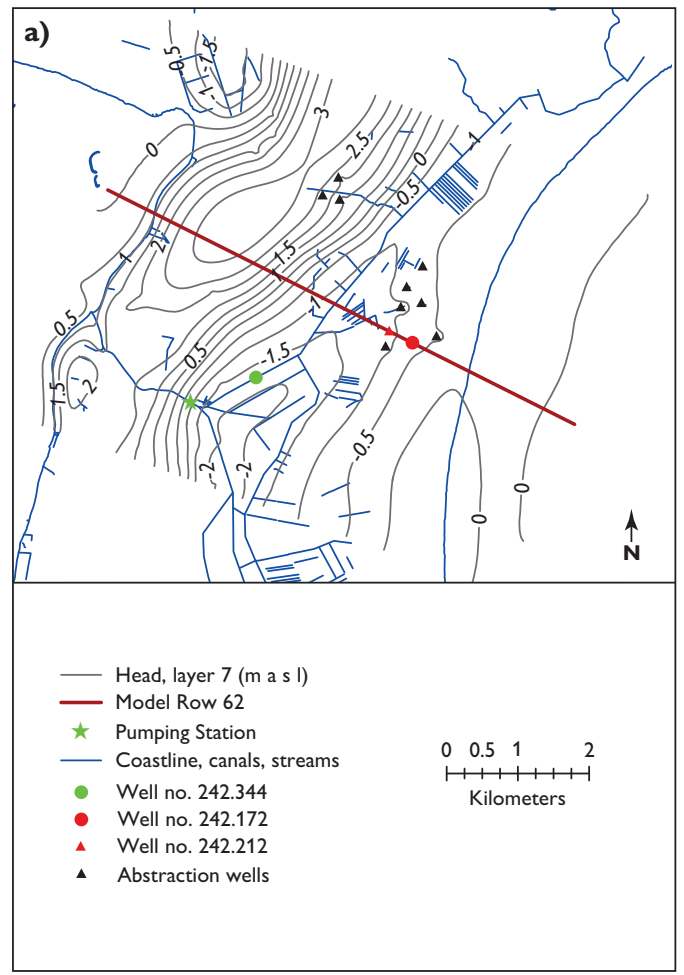

Fig. 7. (a) Groundwater head for main chalk aquifer 2010 situation, (b) flow velocity vectors for cross section model row 62 (see a), (c) measured groundwater head versus modeled head values.

MT3DMS solution scheme. For the two groundwater abstraction wells (242.172 and 242.212) with simulated TDS concentrations between $0.4-0.8 \mathrm{~g} \mathrm{~L}^{-1}$ a $4-6 \%$ reduction in TDS concentrations was found after $100 \mathrm{yr}$ of pumping using a longitudinal dispersivity of $1 \mathrm{~m}$ compared to the estimated value of $8 \mathrm{~m}$. The sensitivity analysis of the MT3D Finite Difference solution scheme showed 5-14\% higher
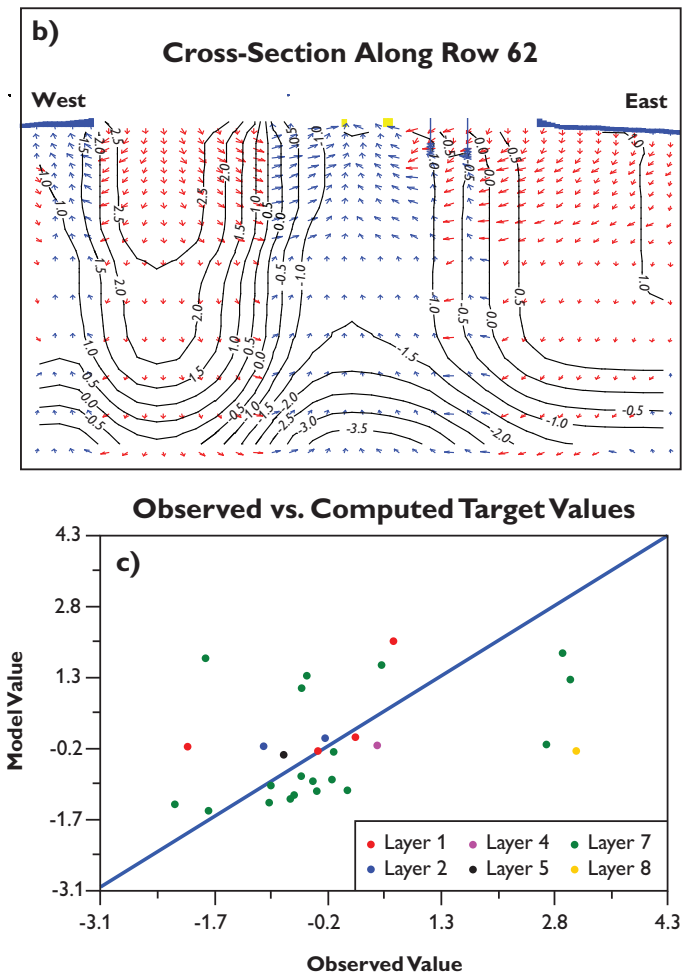
concentrations using the TVD scheme compared to the Finite Difference solution scheme.

\subsection{Simulation of travel times to wells}

MT3DMS/SEAWAT is used for simulation of groundwater age using the MT3DMS Reaction package. Groundwater age is simulated as species number 2 (saltwater is species 
Table 7. Electrical conductivity measured by borehole logging (Log EC) and on water samples in the laboratory (Lab. EC) compared to analyzed chloride concentrations and calculated total dissolved solids (TDS).

\begin{tabular}{lrrrlrrrr}
\hline & $\begin{array}{r}\log \mathrm{EC}_{\mathrm{W}}^{1} \\
\mathrm{mS} \mathrm{m}^{-1} \\
10^{\circ} \mathrm{C}\end{array}$ & $\begin{array}{r}\mathrm{Lab.} \mathrm{EC} \\
\mathrm{mS} \mathrm{m}^{-1} \\
25^{\circ} \mathrm{C}\end{array}$ & $\begin{array}{r}\text { Lab. } \mathrm{EC}^{2} \\
\mathrm{mS} \mathrm{m}^{-1} \\
10^{\circ} \mathrm{C}\end{array}$ & $\begin{array}{l}\mathrm{TDS}^{3} \\
\mathrm{~g} \mathrm{~L}^{-1}\end{array}$ & $\begin{array}{r}\text { Chloride } \\
\mathrm{mg} \mathrm{L}^{-1}\end{array}$ & $\begin{array}{r}\log \mathrm{EC}_{\mathrm{f}}^{4} \\
\mathrm{mS} \mathrm{m}^{-1} \\
10^{\circ} \mathrm{C}\end{array}$ & $\begin{array}{r}\log R \\
\Omega \mathrm{m}\end{array}$ & $\begin{array}{c}f_{\text {form. }}^{5} \\
10^{\circ} \mathrm{C}\end{array}$ \\
\hline $242.44 \mathrm{~B}$ & 100 & 158 & 114 & $\mathbf{1 . 0 4}$ & $\mathbf{2 7 0}$ & 39 & 26 & 2.6 \\
242.178 & 109 & 152 & 109 & $\mathbf{1 . 0 1}$ & $\mathbf{2 5 7}$ & 26 & 38 & 4.2 \\
242.182 & 46 & 66 & 47 & 0.57 & 31 & 13 & 77 & 3.5 \\
242.212 & 83 & 117 & 84 & 0.84 & 185 & & & \\
242.230 & 67 & 98 & 70 & 0.75 & 104 & & & \\
242.232 & 82 & 115 & 83 & 0.86 & 155 & 22 & 45 & 3.7 \\
242.319 & 45 & 67 & 48 & 0.57 & 40 & 10 & 100 & 4.5 \\
242.320 & 42 & 62 & 45 & 0.53 & 32 & 9 & 111 & 4.7 \\
$242.344-20$ & 87 & 134 & 96 & - & 208 & 33 & 30 & 2.6 \\
$242.344-40$ & 374 & 472 & 340 & - & $\mathbf{1 3 1 3}$ & 114 & 9 & 3.3 \\
$242.344-60$ & 535 & 693 & 499 & - & $\mathbf{1 9 9 2}$ & 128 & 8 & 4.2 \\
$242.344-80$ & 1235 & 1285 & 925 & - & $\mathbf{3 9 3 0}$ & 231 & 4 & 5.3 \\
$242.344-95$ & 1996 & 2760 & 1986 & - & $\mathbf{8 9 9 4}$ & 470 & 2 & 4.2 \\
Baltic Sea & - & 1366 & 983 & 7.9 & 4403 & & & \\
\hline
\end{tabular}

${ }^{1}$ Fluid conductivity log. ${ }^{2}$ Calculated as: $\mathrm{EC}_{10}=\mathrm{EC}^{25}(1+a(10-25))$ where $a=0.0187$ (Hayashi, 2004). ${ }^{3}$ Calculated from the chemical analysis of the water sample. ${ }^{4}$ Electrical conductivity of the formation measured by focused induction $\log .{ }^{5}$ Calculated formation factor $\left(f_{\text {form. }}=\mathrm{EC}_{\mathrm{water}} / \mathrm{EC}_{\text {formation }}=\right.$ column $2 /$ column 7.) Note that The European drinking water guideline for electrical conductivity is $250 \mathrm{mS} \mathrm{m}^{-1}$ at $20^{\circ} \mathrm{C}$ this corresponds to approximately $200 \mathrm{mS}^{-1}$ at $10^{\circ} \mathrm{C}$ or $275 \mathrm{mS}^{-1}$ at $25^{\circ} \mathrm{C}$. Bold italic numbers indicate that the EU drinking water guideline $\left(\mathrm{EC}=200 \mathrm{mS}^{-1}\right.$ at $10^{\circ} \mathrm{C}$ or $\left.\left[\mathrm{Cl}^{-}\right]=250 \mathrm{mg} \mathrm{L}^{-1}\right)$ has been breached.

number 1) with "no-sorption" and "zero-order decay". All water in the model starts with an age of zero days, and as the water moves through the model the water is tracked with time.

\subsection{Validation of transport model against hydrochemical and geophysical data}

The 3-D numerical simulations of seawater intrusion have been corroborated by analysis of groundwater chemical data (electrical conductivity, EC; chloride; and total dissolved solids, TDS), groundwater tracer ages $\left({ }^{3} \mathrm{H} /{ }^{3} \mathrm{He}\right.$ dating), and geophysical investigations (borehole logging and airborne electromagnetics/SkyTEM). Geophysical borehole logs from the water supply wells were available at the time of model setup and were applied to, e.g. assist in the definition and distribution of hydraulic parameters in the model. The interpreted SkyTEM measurements, the logging results of the new investigation well and the ${ }^{3} \mathrm{H} /{ }^{3} \mathrm{He}$ tracer ages became available after model setup. Hence, they provide independent data for comparison to and possible validation of the model simulations.

\subsubsection{Hydrochemical and geophysical data corroborating results of the model simulations}

Table 7 compares selected results from laboratory analyses on groundwater samples and geophysical borehole logs in the sampled water supply wells and the Baltic Sea. The presented data focuses on salinity related parameters relevant for evaluating and simulating saltwater intrusion. The data show that chloride concentrations vary from approximately $30 \mathrm{mg} \mathrm{L}^{-1}$ in water supply wells in the new well field 3 in the main groundwater recharge area to more than $4000 \mathrm{mg} \mathrm{L}^{-1}$ in a sample from the Baltic Sea and $9000 \mathrm{mgL}^{-1}$ at a depth of $95 \mathrm{~m}$ below surface in the new investigation well (no. 242.344, Fig. 2).

Figure 8 illustrates the relation between measured chloride and measured and calculated electrical conductivity and TDS, respectively. The shown data are all from the investigated water supply wells and cover salinities around the WHO and EU guideline value for chloride $\left(250 \mathrm{mg} \mathrm{L}^{-1}\right)$ in order to make the resolution as precise as possible around this value. Figure 8 demonstrates the near-perfect linear relationship between the chloride contents and the EC and TDS of the samples around the drinking water standard for chloride in the investigated chalk aquifer.

Hence, the data shown in Table 7 and Fig. 8 can be used to estimate the EC and TDS values corresponding to the drinking water standard for chloride of $250 \mathrm{mg} \mathrm{L}^{-1}$ (Table 8), and thereby facilitating the comparison between model simulations, hydrochemical analyses, airborne and borehole geophysical measurements as well as for estimating the size of the drinking water resource in the area. By using an average formation factor of 4 for the chalk aquifer obtained by geophysical borehole logging in the water supply wells (Table 7) and previous investigations (Larsen et al., 2006; Bonnesen et al., 2009), it becomes possible to estimate the average groundwater conductivity from airborne resistivity 
Table 8. Groundwater electrical conductivity (EC) and TDS content for the investigated chalk aquifer corresponding to the WHO and EU drinking water standard (DWS) for chloride of $250 \mathrm{mg} \mathrm{L}^{-1}$, and a proposed threshold value for chloride of $150 \mathrm{mg} \mathrm{L}^{-1}$ (Hinsby et al., 2008).

\begin{tabular}{llrrrrrrrr}
\hline Quality & & \multicolumn{4}{c}{ Groundwater } & & \multicolumn{2}{c}{ Formation } \\
\cline { 3 - 4 } Indicator & & $\begin{array}{c}\text { Chloride } \\
\mathrm{mg} \mathrm{L}^{-1}\end{array}$ & $\begin{array}{r}\mathrm{TDS} \\
\mathrm{mg} \mathrm{L}^{-1}\end{array}$ & $\begin{array}{r}\mathrm{EC}^{1} \\
\mathrm{mS} \mathrm{m}^{-1}\end{array}$ & $\begin{array}{r}R^{1} \\
\Omega \mathrm{m}\end{array}$ & & $\begin{array}{c}\mathrm{EC}^{2} \\
\mathrm{mS} \mathrm{m}^{-1}\end{array}$ & $\begin{array}{c}R^{2} \\
\Omega \mathrm{m}\end{array}$ \\
\hline \multirow{2}{*}{ chloride } & Threshold & 150 & 803 & 79 & 13 & & $20 / 2$ & $52 / 5$ \\
& DWS & 250 & 1005 & 107 & 9 & & $27 / 3$ & $37 / 4$ \\
\hline
\end{tabular}

${ }^{1}$ At $10{ }^{\circ} \mathrm{C}$ (computed from linear regression lines in Fig. 8). ${ }^{2}$ Electrical conductivity (EC) and resistivity $(R)$ assuming an average formation factor of 4 with a STD of 0.4 (after slash).

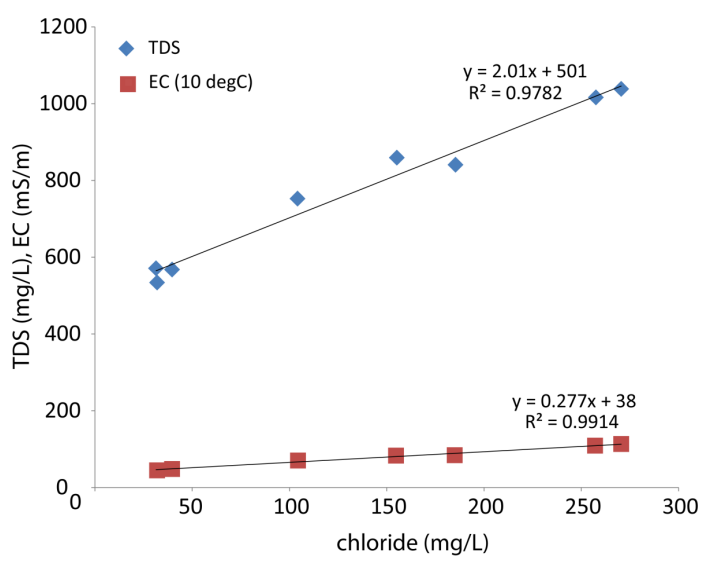

Fig. 8. Relation between measured chloride and measured and calculated electrical conductivity and TDS, respectively.

measurements of the formation, and hence indicate where groundwater complies with the drinking water standard for chloride in the chalk aquifer.

In the investigated chalk aquifer the EC for groundwater corresponding to the drinking water guideline for chloride is $107 \mathrm{mS} \mathrm{m}^{-1}$ (Table 8), and hence much less than the guideline value for $\mathrm{EC}$ itself $\left(250 \mathrm{mS} \mathrm{m}^{-1}\right.$ at $20^{\circ} \mathrm{C}$ corresponds to $\sim 200 \mathrm{mS} \mathrm{m}^{-1}$ at $10^{\circ} \mathrm{C}$ ). The guideline value for chloride is therefore significantly stricter as a quality indicator than the $\mathrm{EC}$ value in the investigated aquifer. Hence, we use the TDS and EC values corresponding to the measured chloride concentrations to develop colour scales that facilitate regional comparison between the results of SWI model simulations and SkyTEM conductivity models. Further, the colour scales are defined such that they clearly indicate where the chloride contents are above (red colour) or below (blue/green colours) drinking water guidelines. Hence the blue and green colours in the plots of model and SkyTEM results in Fig. 9 indicate the size and location of the drinking water resource. Yellow indicates where the groundwater breaches a threshold value of $150 \mathrm{mg} \mathrm{L}^{-1}$ (Hinsby et al., 2008) and may serve as an early warning of significant saltwater intrusion. The comparison of the results from the SWI model simulations and the SkyTEM (Fig. 9) shows that both methods capture the main features of the current fresh and saltwater distribution, e.g. by identifying the two freshwater lenses that have developed below the clayey push moraine hills in the west and the smaller sandy barrier island in the east. Further, both the SkyTEM measurements (SkyTEM resistivity or electrical conductivity models) and the SWI model simulations capture the expected upconing of saltwater below the main drainage canal through the investigation area. However, significant differences between the two methods are also observed as described in the following section.

Geophysical borehole logs (Fig. 10) and chemical analyses on groundwater (Table 7) from the new deep investigation well (well no. 242.344) are in very good agreement, and show that the chloride concentrations of the pore waters in the chalk aquifer increase from values approaching the drinking water guideline value ( $250 \mathrm{mg} \mathrm{L}^{-1}$ of chloride) at a depth of approximately $25 \mathrm{~m}$ below surface to chloride concentrations of the Baltic Sea at a depth of about $80 \mathrm{~m}$ (approx. $4000 \mathrm{mg} \mathrm{L}^{-1}$ ). At a depth of $95-100 \mathrm{~m}$ where the borehole terminates, the chloride concentration is approximately $9000 \mathrm{mg} \mathrm{l}^{-1}$ (Table 7, Fig. 10) or more than twice the concentration of the Western Baltic Sea. Based on previous investigations of deep wells (down to about $400 \mathrm{~m}$ below surface) in limestone and chalk, and the diffusion profiles observed in these (Bonnesen et al., 2009), we estimate that the salinity of chalk reaches the salinity of the cretaceous sea at a depth of approximately $150 \mathrm{~m}$. Hence, both the geophysical borehole $\log$ from the deep investigation well and analyses on groundwater samples collected in the well show that the saltwater interface (here defined as $250 \mathrm{mg} \mathrm{L}^{-1}$ ) is located at approximately $25 \mathrm{~m}$ below surface at the investigation well (Table 7, Fig. 10). This compares well with the results of the SWI model simulations (Fig. 9). In contrast, the saltwater interface estimated by the SkyTEM measurements is located somewhat deeper, at a depth of approximately $40 \mathrm{~m}$ below surface in this location (Fig. 9).

Further, a discrepancy occurs between the apparent salinity of groundwater as modelled by the groundwater model (Fig. 9, upper left panel) and measured by AEM/SkyTEM (Fig. 9, lower left panel) at a distance of approximately 1.5$2.5 \mathrm{~km}$ east of investigation well (no. 242.344). The SkyTEM conductivity model indicate salt groundwater, while the 

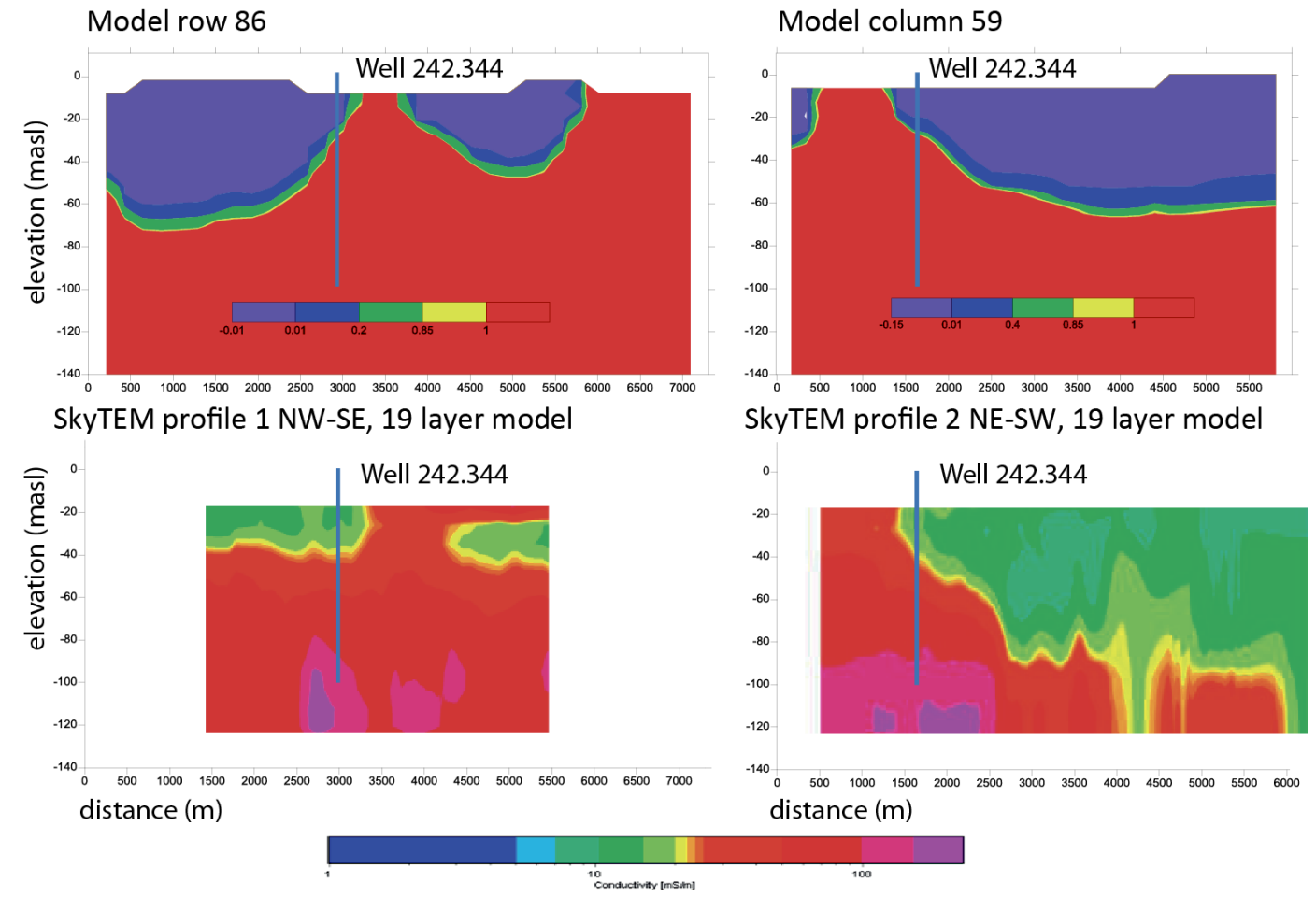

Fig. 9. Comparison between the results of model simulations (upper cross sections) and SkyTEM surveys (lower cross sections). The location of cross sections is indicated on Fig. 6. The colour scales are defined such that blue/green colours indicate freshwater of drinking water quality $\left(\left[\mathrm{Cl}^{-}\right]<250 \mathrm{mg} \mathrm{L}^{-1}\right)$. Yellow is breaching a threshold value of $150 \mathrm{mg} \mathrm{L}^{-1}$, and red breaches the drinking water guideline (Table 7).

groundwater flow (SWI) model indicates fresh groundwater. Based on the data from water supply wells about $1 \mathrm{~km}$ northwest of the cross section and the new investigation well, we estimate that groundwater in the upper $25 \mathrm{~m}$ is fresh and hence that there may be a problem with the SkyTEM interpretation of the groundwater salinity of the upper chalk in this area. Marine Holocene sediments, which may be only partly flushed, occur locally in the area and these may in some cases result in wrong interpretations for the upper chalk just below these. On the other hand, we cannot rule out that the Holocene marine sediments are actually affecting the chloride concentrations in the upper part of the chalk locally. Further investigations in this area are required to resolve this issue. The examples demonstrate that the combined use of geophysical (geoelectrical) data and model simulations will help to increase the understanding of a specific setting (Carrera et al., 2010; Faneca Sànchez et al., 2012) and to identify where additional data are needed to improve the performance of the SWI model and the inversion and interpretation of the SkyTEM measurements. SkyTEM data provide extremely valuable data for model calibration, but they are not free of problems and they should be used jointly with flow and transport (model) inversion when possible (Carrera et al., 2010). Results from groundwater model simulations may also improve the interpretation of the SkyTEM measurements and hence the SkyTEM resistivity (electrical conductivity) models. Especially when combined with results from geophysical borehole logging.

\subsubsection{Estimated ${ }^{3} \mathrm{H} /{ }^{3} \mathrm{He}$ ages and simulated travel times to wells}

Table 9 compares ${ }^{3} \mathrm{H} /{ }^{3} \mathrm{He}$ groundwater ages estimated on groundwater samples collected from the water supply wells to travel times to the wells computed by the established SWI model. The data show a generally quite good agreement between the age estimates, except for well no. 242.319 and 242.320 , where the simulated ages are significantly younger than the tracer estimates. The reason for the discrepancy is currently not known, but it could be a result of diffusive loss of ${ }^{3} \mathrm{H}$ and ${ }^{3} \mathrm{He}$ from fractures to matrix in the approximately $11-\mathrm{m}$-thick clay tills above the chalk aquifer or from fractures to matrix in the aquifer itself. This process removes the tracers from the hydraulic active fractures resulting in tracer groundwater age estimates older than actual groundwater advective ages (LaBolle et al., 2006).

\section{Model results and predictions}

Nine different climate change scenarios have been simulated in this study (Table 2). 
Table 9. Measured ${ }^{3} \mathrm{H} /{ }^{3} \mathrm{He}$ values and estimated ${ }^{3} \mathrm{H} /{ }^{3} \mathrm{He}$ groundwater ages compared to model-simulated travel times in supply wells.

\begin{tabular}{lccccrr}
\hline Well no. & $\begin{array}{c}\mathrm{He}^{4} \text { radio } \\
\mathrm{nmL} \mathrm{cm}{ }^{3}(\mathrm{STP})\end{array}$ & $\begin{array}{c}{ }^{3} \mathrm{H} \\
\mathrm{TU}\end{array}$ & $\begin{array}{c}\mathrm{err}^{3} \mathrm{H} \\
\mathrm{TU}\end{array}$ & $\begin{array}{c}\text { trit- }^{3} \mathrm{He} \\
\mathrm{TU}\end{array}$ & $\begin{array}{r}{ }^{3} \mathrm{H} /{ }^{3} \mathrm{He} \text { age } \\
\text { yr }\end{array}$ & $\begin{array}{r}\text { Simulated travel } \\
\text { times yr }\end{array}$ \\
\hline $242.178(1)$ & $8.97 \times 10^{-4}$ & 0.01 & 0.01 & 0.0 & $>75$ & 113 \\
$242.182(2)$ & $1.02 \times 10^{-4}$ & 0.06 & 0.12 & 0.0 & $>75$ & - \\
$242.212(2)$ & $3.83 \times 10^{-4}$ & -0.01 & 0.01 & 0.0 & $>75$ & 67 \\
$242.230(2)$ & $5.39 \times 10^{-4}$ & 0.09 & 1.06 & 0.0 & $>75$ & 42 \\
$242.231(2)$ & $3.28 \times 10^{-4}$ & 0.01 & 0.15 & 0.0 & $>75$ & 70 \\
$242.232(2)$ & $7.21 \times 10^{-4}$ & 0.01 & 0.02 & 0.0 & $>75$ & 92 \\
$242.239(2)$ & $2.11 \times 10^{-4}$ & 0.01 & 0.01 & 0.0 & $>75$ & 95 \\
$242.317(3)$ & $1.30 \times 10^{-5}$ & 0.05 & 0.02 & 3.3 & 75 & 85 \\
$242.319(3)$ & $1.12 \times 10^{-5}$ & 0.02 & 0.02 & 0.5 & $>75$ & 48 \\
$242.320(3)$ & $1.38 \times 10^{-5}$ & 0.00 & 0.02 & 0.9 & $>75$ & 45 \\
\hline
\end{tabular}

* Numbers in parentheses indicate the well field each well belongs to.

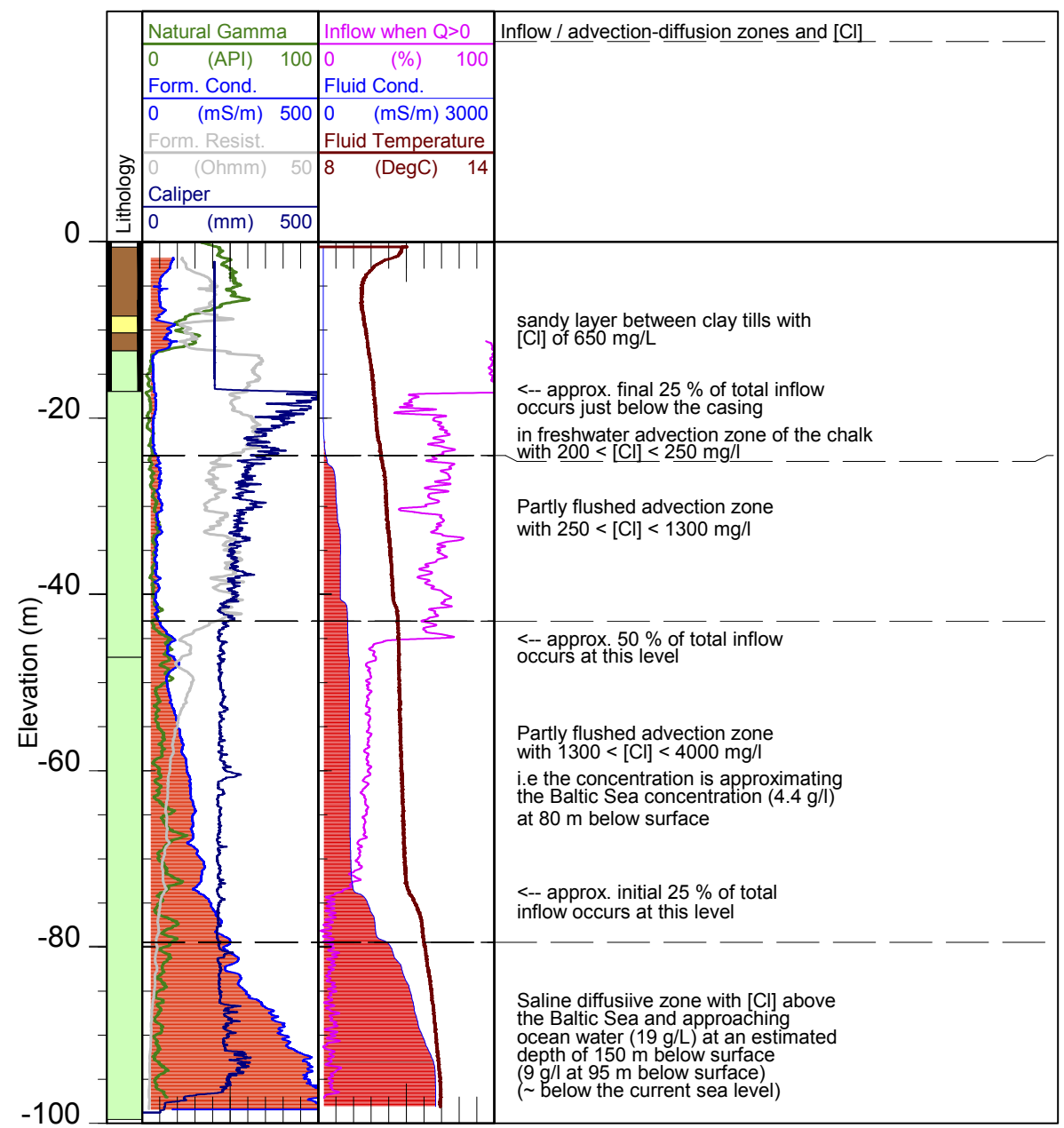

Fig. 10. Results of geophysical borehole logs from the new deep investigation well (Well no. 242.344, Figs. 2 and 9). 


\subsection{Present situation}

In Scenario 0 no climate change is implemented and only effects of the hydro-geographical changes including the drainage from 1870 and groundwater abstraction from 1960 is affecting the change in TDS concentration in the aquifer and groundwater wells. The results of the numerical simulation are first described by time series of TDS concentration from two groundwater abstraction wells, well no. 242.172 and 242.212 (Fig. 11). Both wells show an increasing TDS concentration from the start of groundwater abstraction in 1960 until a maximum is seen around 2010. Beyond this time a minor decrease in concentration is seen, most significantly over the following $200 \mathrm{yr}$, whereafter the changes in concentrations are marginal.

Figure $12 \mathrm{a}$ and $\mathrm{b}$ show that freshwater lenses are generated under both the barrier islands to the east and the push moraine hills west of the drainage canal, where the lens on the western part is much deeper than the one on the eastern part due to higher elevations of the groundwater table. At the western part a single flow system is developed, showing a nearly symmetrical flow net with a groundwater divide located in the central part and groundwater discharging to the drainage canal and the strait of Guldborgsund, respectively. The freshwater lens extends to approximately $-80 \mathrm{~m}$ a.s.l. Below the lens the low permeability units of the chalk formation is situated. The flow system to the east of the drainage canal is somewhat different. A groundwater divide is located close to the east coast and a local groundwater flow system is developed at the top of the profile where groundwater discharges to the Baltic Sea in the eastern, near-shore area, while groundwater recharging the rest of the aquifer flows towards the west. Below, a regional flow system is found where groundwater flows to the west. Hence, most of the groundwater recharge flows towards the abstraction wells and the drainage canals. Below the freshwater lens, saltwater from the Baltic Sea in the east flows towards the drainage canal. In Fig. 12a the upconing effect of the drainage canal system is clearly seen on the freshwater-saltwater distribution. Comparison to the cross section with no pumping (Fig. 12b) reveals that upconing also takes place at the two abstraction wells. It is also seen that elevated chloride concentrations in the shallow system is primarily caused by saltwater intrusion from the sea, whereas upward migration of residual saltwater from the deeper chalk formations is negligible.

\subsection{Scenario 1 (best estimate)}

Scenario 1 is considered to represent the most likely estimate of future changes in sea level and groundwater recharge. However, large uncertainties are associated with this projection and a sensitivity analysis on this reference scenario is therefore carried out.

When sea level and groundwater recharge are increased simultaneously almost no effect on the saltwater distribution is
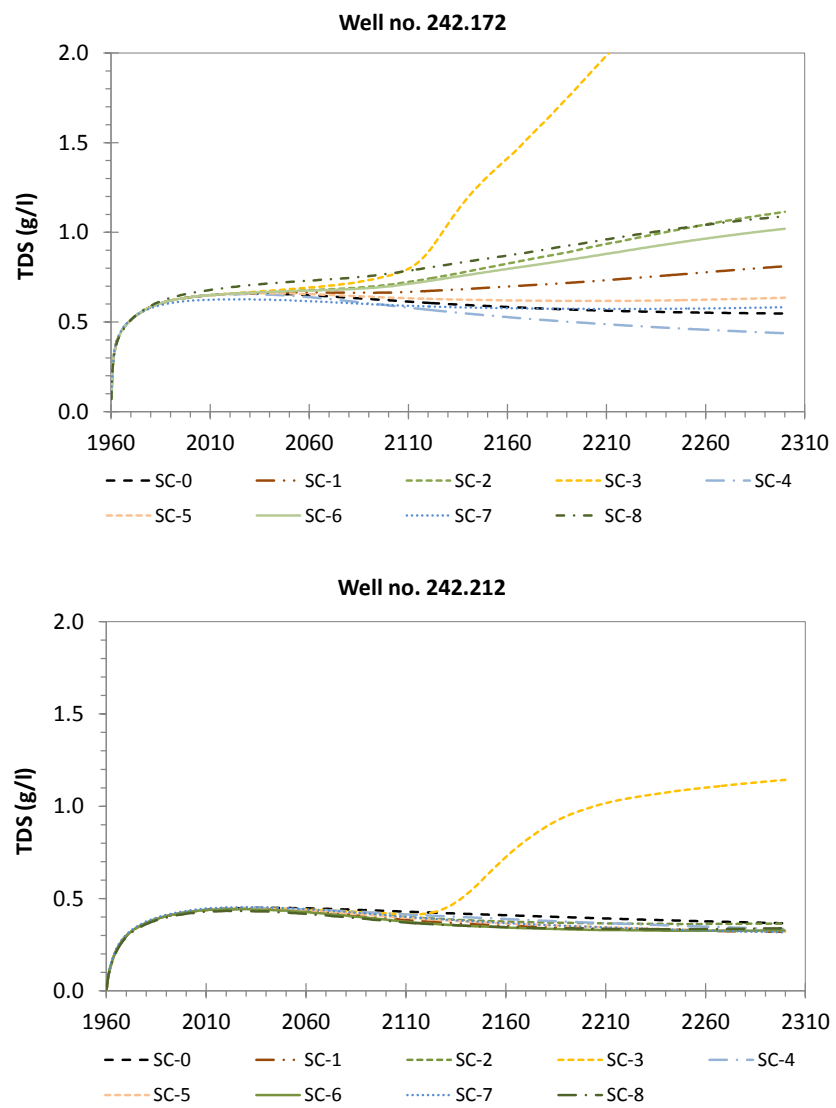

Fig. 11. Model simulation of TDS concentrations $\left(\mathrm{g} \mathrm{L}^{-1}\right)$ in two groundwater abstraction wells for 9 scenarios (Table 2).

observed to the west of the drainage canal (Fig. 12e). The expected saltwater intrusion caused by sea level rise is balanced by the increase in groundwater recharge and hence groundwater level. The situation on the eastern part is quite different, where an inland movement of saltwater from the Baltic Sea below the freshwater lens is observed (Fig. 12e and f). The eastern flow system is characterized by the regional flow system that connects the drainage canal to the sea through high permeable fractured chalk., The rising sea level results in an increasing gradient towards the drainage canal where the stage is constant despite the increase in sea level and recharge. Hence, saltwater intrusion is more pronounced in this situation. Under the drainage canal the picture is more diverse, with increasing TDS content in parts of the aquifer and decreasing TDS in other parts, here the effect of the increasing recharge counteracts to some extent the increasing sea level (Fig. 12c-f).

The TDS concentration simulated for well no. 242.172 (Fig. 11) shows for Scenario 1 an increasing concentration from 2100 and onwards and the increase has not stabilized in year 2300. For well no. 242.212, which is located further from the coast and closer to the drainage canals, only a minor 

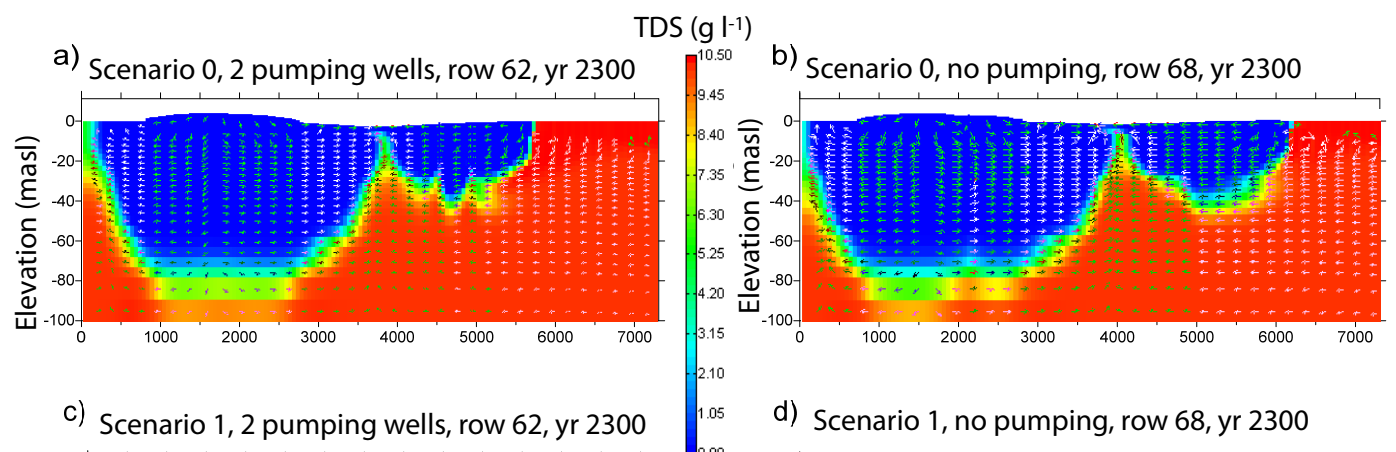

d) Scenario 1, no pumping, row 68, yr 2300
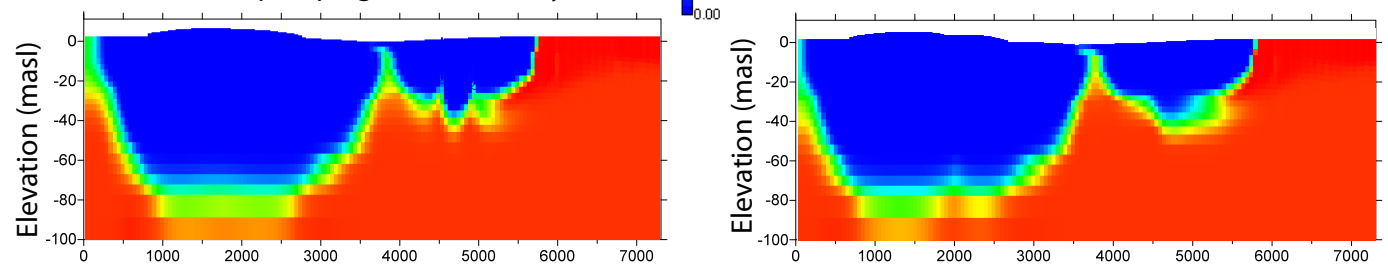

e) Scenario 1 - Scenario 0, with pumping, row 62

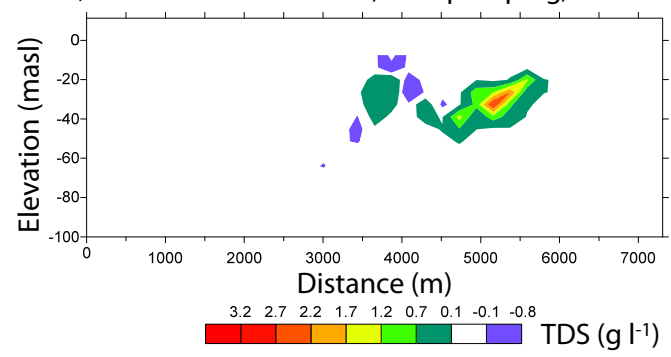

f) Scenario 1 - Scenario 0, no pumping, row 68

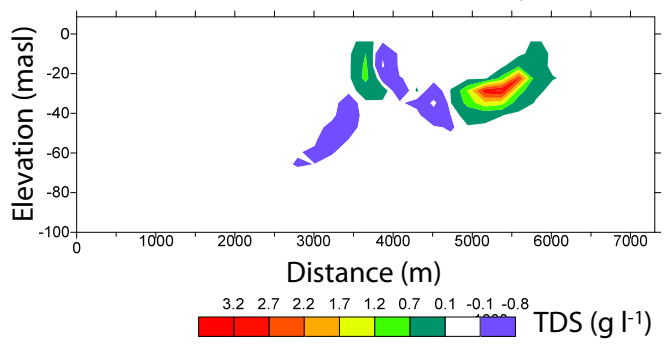

Fig. 12. Simulated freshwater-saltwater distribution in 2300 (scale TDS $\left(\mathrm{g} \mathrm{L}^{-1}\right)$ ), (a) basic scenario 0, cross section with pumping wells and flow velocity vectors (row 62), (b) basic scenario 0 , cross section with no pumping and flow velocity vectors (row 68), (c) reference scenario 1, cross section with pumping wells (row 62), (d) reference scenario 1, cross section with no pumping (row 68), (e) scenario 1scenario 0 , difference in TDS $\left(\mathrm{mg} \mathrm{L}^{-1}\right)$, cross section with pumping wells (row 62), (f) scenario 1 -scenario 0 , difference in TDS (mg L ${ }^{-1}$ ), cross section with no pumping (row 68).

decrease in TDS concentration compared to Scenario 0 is indicated by the model simulations (Fig. 11).

\subsection{Changing recharge (Scenario 2 and 3)}

In Scenario 2 groundwater recharge is reduced from +15 to $0 \%$. For well 242.172 , located closest to the sea, a gradual increase in chloride concentration is found (Fig. 11a), indicating that the thickness of the freshwater lens is reduced and more chloride is mixed into the abstracted water. Well no. 242.212 is not affected within the simulation period (Fig. 11b).

The effects are more significant when the recharge is decreased further to $-15 \%$ while sea level rise remains at $0.75 \mathrm{~m}$ (Scenario 3). For the groundwater abstraction wells a 3-5-fold increase in concentration is found (well 242.172 and 242.212, Fig. 11). Especially at the well close to the east coast, a dramatic increase in concentration is observed. An increase in salinity of the eastern freshwater lens is also seen on the cross sections (Fig. 13a and b) and the increase is observed all the way to the top of the saturated zone.
The reason for this dramatic change is explained by Fig. 14. When groundwater recharge is decreased, the groundwater divide is displaced to the east and the local shallow flow system at the top eastern corner disappears. Hence, saltwater from the sea flows directly into the freshwater lens and freshwater is displaced from the area resulting in an increase in concentration for the entire lens system (Fig. 13a and $b$ ). Because of recharging freshwater, the concentrations in the shallow parts of the aquifer do not reach the level of the sea. It should be noted that the concentration distribution has not reached a steady-state situation at year 2300 and that the concentration changes shown in Fig. 13a and b, therefore, do not represent the final state of the system.

Figure 13a and $b$ also show that the decrease in groundwater recharge results in a reduction of the freshwater lens of the area west of the drainage canal where the transition zone has moved 10-20 m upwards. This is a result of a decrease in the elevation of the groundwater table, which causes the saltwater-freshwater interface to move up. 

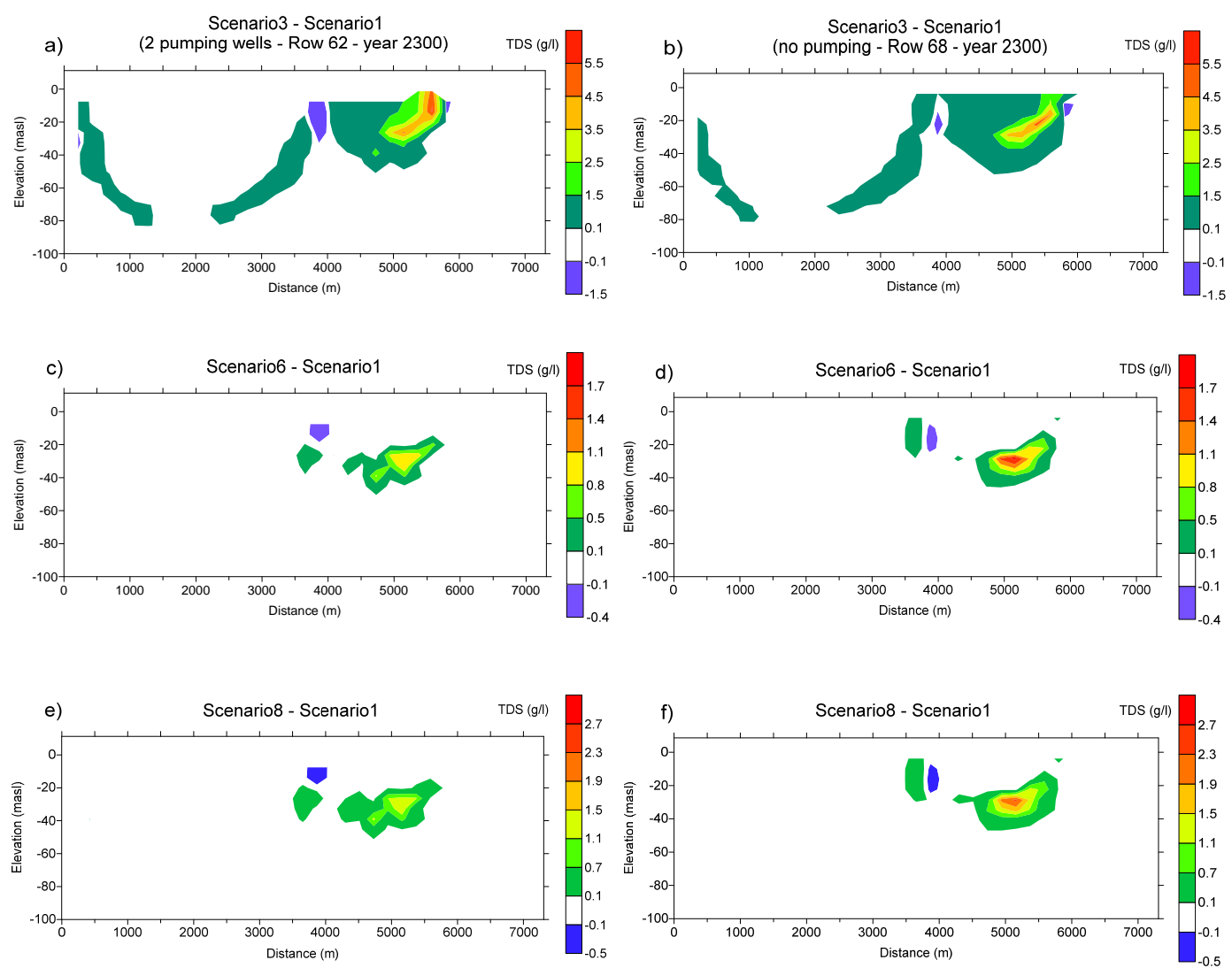

Fig. 13. Difference in simulated freshwater-saltwater distribution in 2300 (scale TDS $\left(\mathrm{g} \mathrm{L}^{-1}\right)$ ), (a) scenario 3-scenario 1, cross section with pumping wells (row 62), (b) scenario 3-scenario 1, cross section with no pumping (row 68), (c) scenario 6-scenario 1, cross section with pumping wells (row 62), (d) scenario 6-scenario 1, cross section with no pumping (row 68), (e) scenario 8-scenario 1, cross section with pumping wells (row 62), (f) scenario 8-scenario 1, cross section with no pumping (row 68).

\subsection{Changing sea level (Scenario 4-6)}

In scenarios 4, 5 and 6 the sea level is increased successively from 0 to $0.5 \mathrm{~m}$ and $1.0 \mathrm{~m}$. In the area west of the drainage canal the changes in sea level have almost no impact on the concentration distribution (Fig. 13c and d). As sea level is increased, the elevation of the groundwater table also increases. This corroborates with the findings of Chang et al. (2011) who found that sea level changes did not result in significant impacts on saltwater intrusion for constant flux systems. However, on the eastern side of the drainage canal the concentration of the abstracted water at the well closest to the coast (242.172) is sensitive to the changes (Fig. 11). If zero sea level rise is specified, sea water intrusion is reduced both compared to scenario 0 and 1 , and when the sea level is increased the concentration at the well gradually increases too. Contrary to the western flow system, the drainage canal is connected to the sea through geological layers with higher permeability, and changes in sea level therefore affect the gradient and hence the location of the mixing zone between the fresh and saltwater. At well 242.212 almost no impacts of sea level changes are observed (Fig. 11b). Here, recharging freshwater from above prevents saltwater intrusion.

\subsection{Effect of drainage system (Scenarios 7-8)}

In Scenarios 7 and 8 the impact of stage in the drainage canals is investigated. If the stage is increased the hydraulic gradient from the sea to the canal is reduced and a marginal reduction in saltwater intrusion is found (Fig. 11). However, a decrease of the stage by only $30 \mathrm{~cm}$ has a relatively large effect on the concentration of well 242.172 (Fig. 11). At the end of the simulation period the concentration has increased by approximately $50 \%$ compared to scenario 1 . Figure $13 \mathrm{e}$ and $f$ show that relatively large differences in concentration distribution are found below the wells. As the hydraulic head at the canal is dictated by the specified stage, the gradient from the sea increases, which results in additional sea water intrusion. 


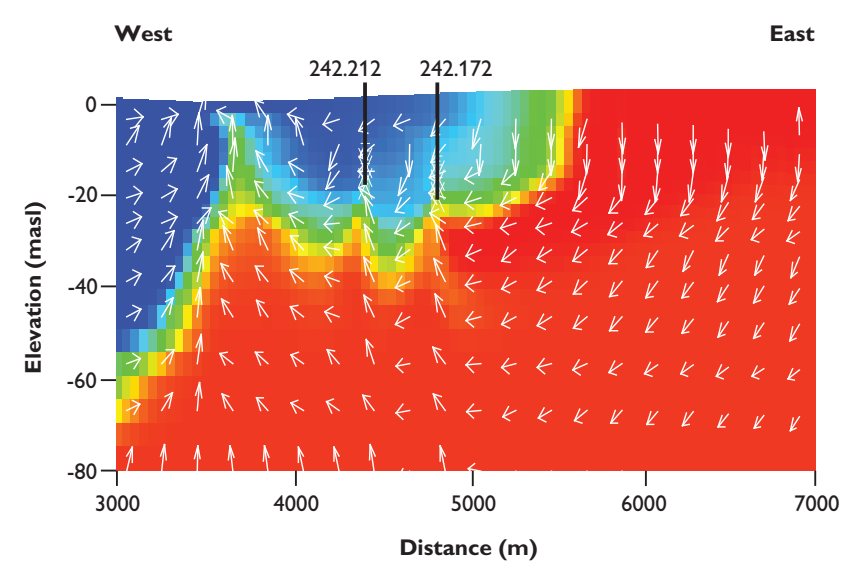

Fig. 14. Flow vectors for scenario 3 in year 2300, model row 62 with two pumping wells. Zoomed in on the eastern freshwater lens. Logarithmic flow vector scale and exaggerate vertical velocity flow vectors are used.

\section{Discussion}

\subsection{Salinity trends in water supply wells}

According to the model simulations some abstraction wells have reached equilibrium conditions before 2010. After the start of pumping, upconing of saline water takes place and the TDS contents in the wells are seen to increase to a certain maximum level. Subsequently, a minor decrease in TDS content towards a constant level is observed, when all other parameters are unchanged. This dynamic is due to the delayed effect of continuous recharge to the aquifer. Other wells have just reached a new equilibrium around 2010 and the TDS content has stopped increasing indicating that some of the existing abstraction wells could continue to be in use with a proper abstraction scheme if sea level and climate do not change. Some of these wells might even experience a minor decrease in chloride content. A third group of abstraction wells still see an increase in chloride content after $50 \mathrm{yr}$ of abstraction. Which situation applies to a given well not only depends on the distance to the shore but to a high extent also the hydrogeological setting around the well.

\subsection{Comparison of SWI model results with geochemical and geophysical data}

The comparison of simulation results with independent geochemical (chloride, TDS) and geophysical data (SkyTEM and borehole logging, Sect. 4.5.1) shows a reasonable agreement between the overall distribution of freshwater and saltwater as mapped and simulated by the different methods (Figs. 8 and 10), especially considering that the geophysical data from the airborne EM, and the borehole logging results from the deep investigation well were not available during setup of the model, and hence were not applied for e.g. defining hydraulic parameters and the location of the salt/freshwater boundaries. When analyzing results more closely it becomes clear that some discrepancies exist. For instance when comparing the location of the interface between fresh and saline groundwater (Fig. 9), it is found that the freshwater generally penetrates deeper in the SWI model than in the SkyTEM measurements in the east-west trending cross section to the left, while the opposite is the case for the freshwater penetration in the north-south trending cross section to the right. Note that the model agrees with the borehole log (incl. chloride analyses on groundwater sampled from the well at specific depths) that the chloride drinking water standard $\left(250 \mathrm{mg} \mathrm{L}^{-1}\right)$ is breached below a depth of approximately $25 \mathrm{~m}$ at the $100 \mathrm{~m}$ deep investigation well, while the SkyTEM measurements indicate a depth of $40 \mathrm{~m}$ to this interface. However, both SkyTEM and model results agree that the groundwater chloride concentrations exceed the drinking water standard in at all depth in the reclaimed land east of the drainage canal. Hence, the performance of the SWI model may be fine-tuned to capture the salinity variations at the canal and at the water supply wells, when all collected data including borehole logging are used for cross validation from both the SWI model and the airborne mapping of subsurface resistivity (Comte and Banton, 2007; Comte et al., 2010). Joint inversion of both airborne geoelectromagnetic measurements and SWI model data (Carrera et al., 2010) will most probably improve both types of data models i.e. the electrical resistivity/conductivity subsurface model obtained from SkyTEM measurements and the performance of the SWI model.

\subsection{Comparison of travel time simulations and ${ }^{3} \mathrm{H} /{ }^{3} \mathrm{He}$ groundwater ages}

Estimation of travel times and groundwater ages is not a simple task and is associated with considerable uncertainties whether estimated by model simulations or environmental tracers such as ${ }^{3} \mathrm{H} /{ }^{3} \mathrm{He}$ (LaBolle et al., 2006; Troldborg et al., 2008). ${ }^{3} \mathrm{H} /{ }^{3} \mathrm{He}$ groundwater ages are generally computed by assuming piston flow and utilizing more than $50 \mathrm{yr}$ of ${ }^{3} \mathrm{H}$ measurements in precipitation (known input function) and a half-life of ${ }^{3} \mathrm{H}$ of $12.3 \mathrm{yr}$, for the decay to ${ }^{3} \mathrm{He}$. The ${ }^{3} \mathrm{H} /{ }^{3} \mathrm{He}$ dating method is the most widely used and tested method for dating young groundwater (Cook and Herczeg, 2000), however, the assumption of piston flow does not hold in complex geological and/or dual porosity settings and ${ }^{3} \mathrm{H} /{ }^{3} \mathrm{He}$ "piston flow ages" and simulated travel times to wells may differ considerably, especially in such settings (Troldborg et al., 2008). Still, both methods contribute to the understanding of solute transport and flow dynamics in the investigated systems, and combined with analyses of contaminants and general geochemistry, they provide valuable data for the understanding of the temporal and spatial evolution of the groundwater quality (Hinsby et al., 2001, 2007). In the present study there is a quite good agreement between the relatively old pre-modern groundwater ages ( $>50 \mathrm{yr}$, Hinsby et al., 2001) 
estimated by the two methods, and between the estimated groundwater ages and the general hydrochemistry (the fact that no human impacts/contamination are observed in the aquifer). The groundwater ${ }^{3} \mathrm{H} /{ }^{3} \mathrm{He}$ age estimations indicate relative ages of more than $75 \mathrm{yr}$ for most wells. However, as generally neither ${ }^{3} \mathrm{H}$ nor tritiogenic ${ }^{3} \mathrm{He}$ can be measured in the collected groundwater samples no "absolute" ${ }^{3} \mathrm{H} /{ }^{3} \mathrm{He}$ groundwater age can be estimated. This indicates that the flow system of the chalk aquifer is efficiently isolated from the upper shallow groundwater flow system by the extensive system of drainage canals developed in the late 19th century and the clay till aquitard above the chalk. The drainage system drains away the major part of the recharged groundwater, and maintains upward hydraulic gradients that prevent significant recharge of the chalk aquifer in large parts of the investigated area. However, both the flow through the clay till in recharge areas and the groundwater flow from the chalk to the drainage canals in discharge areas are limited compared to the flow in the drainage canals. The latter is corroborated by the fact that no increased chloride contents can be observed in the canals despite the fact that the canals have a significant impact on saltwater intrusion in the chalk according to the model simulations. This is discussed further in the next section.

\subsection{Development scenarios for the investigated area in the 21 st century}

The reference scenario, where the effects of both sea level rise and an increase in groundwater recharge were quantified, revealed that only small effects on the saltwater intrusion are found. An exception is areas with head-controlled boundaries, which in our case is represented by the drainage canal in the central part of the island. The fixed head at the drainage canal results in an increasing saltwater intrusion and hence increasing concentrations in the abstraction well closest to the sea. These findings agree well with Werner and Simmons (2009), who found that saltwater intrusion might be significant for head-controlled systems.

The sensitivity analysis on the future scenario that is expected to represent the future changes most realistically (scenario 1) showed that sea level rise has no impact on saltwater intrusion for the area to the west of the drainage canal to which the sea is not well connected hydraulically. However, for the eastern area where the drainage canal is well connected to the sea, saltwater intrusion is sensitive to sea level changes. However, the changes in sea level have to be relatively large before a significant effect is observed.

Saltwater intrusion is found to be more sensitive to realistic changes in groundwater recharge both for the areas with flux controlled and head-controlled boundaries. At the western side of the drainage canals the groundwater head decreases in response to a reduction in recharge. This causes the freshwater lens to reduce in volume as the freshwatersaltwater interface move upwards. To the east of the drainage canals a significant increase in saltwater intrusion is observed in response to the reduction in recharge and hence groundwater head. The situation is intensified because the groundwater divide is displaced towards the sea, which results in increased sea water intrusion.

Saltwater intrusion is also sensitive to the stage of the drainage canal. If the water level of the canal is reduced by $30 \mathrm{~cm}$ a significant increase in saltwater intrusion is found. Due to recent flooding problems of residential and agricultural areas (caused by cloud bursts), a public pressure for reducing the general stage of the canal system might emerge. However, this will increase the need for water to be pumped out of the area, and will as well increase the sea water intrusion bringing the coastal wells more at risk of increasing chloride concentrations under a changed climate. For the most likely climate change scenario (scenario 1 ) the abstraction wells at risk of increasing chloride concentrations above the drinking water standards are the 2-3 wells located closest to the eastern coast line. These wells account for around $20 \%$ of the total abstraction or $50000 \mathrm{~m}^{3} \mathrm{yr}^{-1}$.

Combinations of the changes examined above, i.e. decreasing groundwater recharge, increasing sea level and decreasing stage in the drainage canal will be critical, especially for the freshwater resources to the east of the former lagoon. However, the system is found to react relatively slowly on the imposed stresses and a proper monitoring system, e.g. using continuous sampling of chloride concentrations or EC from wells located relatively close to the Baltic Sea coast could provide the waterworks with an early warning system that enables them to take appropriate measures in case of increasing saltwater intrusion, e.g. to find locations for new well fields. Alternatively, measures to control saltwater intrusion such as the introduction of hydraulic barriers (Abarca et al., 2006; Misut and Voss, 2007; Pool and Carrera, 2010) could be introduced. Effects and benefits of different hydraulic barrier designs should be further analysed as the application of such tools will most probably become of increasing importance for sustainable water management in the investigated area and in many other coastal regions in the future, especially in regions with a high population density.

Other effects of projected climate change impacts include an increase in the number and size of extreme events resulting in floodings along drainage canals if measures are not taken to avoid this. The number of such floodings has increased in recent decades (the latest occurred in August 2011 while the authors were doing field work in the area) as the capacity of the pumping station and the drainage system is becoming too small. Hence, to minimize the risk of future flooding in the area the capacity of the pumping station and the drainage canals have to be increased by at least $20 \%$ according to the SWI model. Further, we propose that the most low-lying parts of the area to the east of the pumping station, which in the early 19th century was a wetland, are prepared for controlled emergency flooding e.g. by introduction of a few flow controlled sluice gates in the main canals just 
before the pumping station for intelligent flood risk management (e.g. Tang et al., 2010). This would reduce the potential damage of the flooding considerably.

\section{Conclusions}

In this study SWI modeling of a real-world case demonstrates the importance and effect of changes in sea level and groundwater recharge on saltwater intrusion into confined and unconfined coastal aquifers, where the groundwater head is controlled by drainage canals. A 3-D density-dependent numerical groundwater model was set up for the groundwater abstraction areas including a larger artificial drainage canal system located centrally in the area. The transition over the last centuries from an open brackish lagoon to a wetland, and later to reclaimed land changed the freshwater/saltwater distribution in the chalk aquifer located between the coast and the drained area. The model studies of four transition phases showed that the chalk aquifer at the eastern coast of the island of Falster is affected by seawater intrusion and that the system had reached a new equilibrium before the time where extensive groundwater abstraction started in the 1960s.

The SWI model has been corroborated against geophysical (AEM/SkyTEM and borehole logging) and hydrochemical data. In general a reasonable agreement was found between the geophysical surveys of apparent aquifer resistivities, measured chloride concentrations and the SWI simulations, although significant differences can also be found. An analysis of all the compiled data clearly indicate that joint inversion of the SWI and subsurface electrical resistivity/conductivity models obtained from airborne measurements will improve the performance of both types of models, especially when detailed data from geophysical borehole logging are also available.

The study shows that saltwater intrusion is sensitive to changes in sea level, groundwater recharge and stage of the drainage canals. However, the boundary conditions of the examined system are important for the resulting effects. For the system with flux controlled boundary conditions, only changes in groundwater recharge had an effect of the saltwater distribution, whereas for the system with head-controlled boundary conditions changes in recharge, sea level and the boundary itself (the stage of the canal) were found to be important for saltwater intrusion. For the actual system, changes in recharge were found to be the most important factor, whereas minor sea level rises do not seem to affect the sea water intrusion as much. For the abstraction wells at risk the model studies show that the chloride concentrations are most sensitive to the stage of the drainage canals and to the groundwater recharge. However, the combination of significant changes in groundwater recharge, sea level rise, groundwater abstraction, and canal maintenance are crucial for the development of the groundwater quality. The established SWI model including the interaction between groundwater, drainage canals, and the sea, is an important tool in future land use planning and water management for the area in a changing climate. Such models will be needed to assess climate change impacts, minimize flooding risks, and maintain a sustainable water resource in many coastal areas, globally.

Acknowledgements. The study was part of the BaltCICA project (http://www.baltcica.org) partly financed by the EU Baltic Sea Region Programme 2007-2013, European Union (European Regional Development Fond) and partly by a grant from the Danish Strategic Research Council for the project Centre for Regional change in the Earth System (CRES - http://www.cres-centre.net). The work was carried out in cooperation with Marielyst Waterworks, Danish Nature Agency, Guldborgsund Municipality, and Bøtø Nor Land Reclamation Association. The authors would especially like to thank the Danish Nature Agency for providing additional SkyTEM data for the study area. Finally, we acknowledge Claus Clausen and Carsten Nielsen of the Marielyst Waterworks for their skillful assistance in the field.

Edited by: P. de Louw

\section{References}

Aarhus Geophysics: Aarhus Workbench, available online at: http: //www.aarhusgeo.com/Workbench/aarhus-workbench.html (last access: 29 March 2012), 2009.

Abarca, E., Vazquez-Sune, E., Carrera, J., Capino, B., Gamez, D., and Batlle, F.: Optimal design of measures to correct seawater intrusion, Water Resour. Res., 42, W09415, doi:10.1029/2005WR004524, 2006.

Anderman, E. R. and Hill, M. C.: MODFLOW-2000, the U.S. Geological Survey Modular Ground-Water Model - Documentation of the Hydrogeologic-Unit Flow (HUF) package, US Geological Survey Open-File Report 00-342, US Geological Survey, Reston, VA, 2000.

Auken, E., Violette, S., d'Ozouville, N., Deffontaines, B., Sorensen, K. I., Viezzoli, A., and de Marsily, G.: An integrated study of the hydrogeology of volcanic islands using helicopter borne transient electromagnetic: Application in the Galapagos Archipelago, C.R. Geosci., 341, 899-907, 2009a.

Auken, E., Christiansen, A. V., Westergaard, J. H., Kirkegaard, C., Foged, N., and Viezzoli, A.: An integrated processing scheme for high-resolution airborne electromagnetic surveys, the SkyTEM system, Expl. Geophys., 40, 184-192, 2009b.

Bonnesen, E. P., Larsen, F., Sonnenborg, T. O., Klitten, K., and Stemmerik, L.: Deep saltwater in Chalk of North-West Europe: origin, interface characteristics and development over geological time, Hydrogeol. J., 17, 1643-1663, 2009.

Brettmann, K., Jensen, K., and Jakobsen, R.: Tracer Test in Fractured Chalk, 2. Numerical-Analysis, Nord. Hydrol., 24, 275-296, 1993.

Buckley, D. K., Hinsby, K., and Manzano, M.: Application of geophysical borehole logging techniques to examine coastal aquifer palaeohydrogeology, Geological Society Special Publications, 189, 251-270, 2001. 
Carrera, J., Hidalgo, J. J., Slooten, L. J., and Vazquez-Sune, E.: Computational and conceptual issues in the calibration of seawater intrusion models, Hydrogeol. J., 18, 131-145, 2010.

Chang, S. W., Clement, T. P., Simpson, M. J., and Lee, K.: Does sea-level rise have an impact on saltwater intrusion?, Adv. Water Resour., 34, 1283-1291, 2011.

Comte, J. and Banton, O.: Cross-validation of geo-electrical and hydrogeological models to evaluate seawater intrusion in coastal aquifers, Geophys. Res. Lett., 34, L10402, doi:10.1029/2007GL029981, 2007.

Comte, J., Banton, O., Join, J., and Cabioch, G.: Evaluation of effective groundwater recharge of freshwater lens in small islands by the combined modeling of geoelectrical data and water heads, Water Resour. Res., 46, W06601, doi:10.1029/2009WR008058, 2010.

Cook, P. G. and Herczeg, A. L. (Eds.): Environmental tracers in subsurface hydrology, Kluwer Acedemic Publishers, Boston, 529 pp., 2000.

de Louw, P. G. B., Eeman, S., Siemon, B., Voortman, B. R., Gunnink, J., van Baaren, E. S., and Oude Essink, G. H. P.: Shallow rainwater lenses in deltaic areas with saline seepage, Hydrol. Earth Syst. Sci., 15, 3659-3678, doi:10.5194/hess-15-36592011, 2011.

Doherty, J.: PEST - Model-Independent Parameter Estimation, User Manual, 5th Edn., Watermark Numerical Computing, Brisbane, Australia, 2005.

Essink, G. H. P. O.: Salt water intrusion in a three-dimensional groundwater system in the Netherlands: A numerical study, Transp. Porous Media, 43, 137-158, 2001.

Essink, G. H. P. O., van Baaren, E. S., and de Louw, P. G. B.: Effects of climate change on coastal groundwater systems: A modeling study in the Netherlands, Water Resour. Res., 46, W00F04, doi:10.1029/2009WR008719, 2010.

Faneca Sànchez, M., Gunnink, J. L., van Baaren, E. S., Oude Essink, G. H. P., Siemon, B., Auken, E., Elderhorst, W., and de Louw, P. G. B.: Modelling climate change effects on a Dutch coastal groundwater system using airborne electromagnetic measurements, Hydrol. Earth Syst. Sci., 16, 4499-4516, doi:10.5194/hess-16-4499-2012, 2012.

Feseker, T.: Numerical studies on saltwater intrusion in a coastal aquifer in northwestern Germany, Hydrogeol. J., 15, 267-279, 2007.

Goes, B. J. M., Essink, G. H. P. O., Vernes, R. W., and Sergi, F.: Estimating the depth of fresh and brackish groundwater in a predominantly saline region using geophysical and hydrological methods, Zeeland, the Netherlands, Near Surf. Geophys., 7, 401-412, 2009.

Harbaugh, A. W., Banta, E. R., Hill, M. C., and McDonald, M. G.: MODFLOW-2000, the U.S. Geological Survey modular groundwater model: user guide to modularization concepts and the ground-water process, US Geol Surv Open-File Rep. 00-92, Reston, VA, 2000.

Hayashi, M.: Temperature-electrical conductivity relation of water for environmental monitoring and geophysical data inversion, Environ. Monit. Assess., 96, 119-128, 2004.

Henriksen, H. J., Troldborg, L., Nyegaard, P., Sonnenborg, T., Refsgaard, J., and Madsen, B.: Methodology for construction, calibration and validation of a national hydrological model for Denmark, J. Hydrol., 280, 52-71, 2003.
Henriksen, H. J., Troldborg, L., Hojberg, A. L. ,and Refsgaard, J. C.: Assessment of exploitable groundwater resources of Denmark by use of ensemble resource indicators and a numerical groundwater-surface water model, J. Hydrol., 348, 224-240, 2008.

Hinsby, K., Edmunds, W. M., Loosli, H. H., Manzano, M., Condesso de Melo, M. T., and and Barbecot, F.: The modern water interface: recognition, protection and development - advance of modern waters in European aquifer systems, Geological Society Special Publications, 189, 271-288, 2001.

Hinsby, K., Purtschert, R., and Edmunds, W. M.: Groundwater Age and Quality, in: Groundwater Science and Policy: An International Overview, edited by: Quevauviller, P., RSC Publishing, London, 217-239, 2007.

Hinsby, K., de Melo, M. T. C., and Dahl, M.: European case studies supporting the derivation of natural background levels and groundwater threshold values for the protection of dependent ecosystems and human health RID C-1806-2008, Sci. Total Environ., 401, 1-20, 2008.

Højberg, A. L., Troldborg, L., Nyegaard, P., Ondracek, M., Stisen, S., Christensen, B. S. B., and Nørgaard, A.: National Vandressource Model: Sjælland, Lolland, Falster og Møn - Opdatering januar 2008, GEUS rapport 2008/65, København, 2008.

Jørgensen, F., Scheer, W., Thomsen, S., Sonnenborg, T. O., Hinsby, K., Wiederhold, H., Schamper, C., Burschil, T., Roth, B., Kirsch, R., and Auken, E.: Transboundary geophysical mapping of geological elements and salinity distribution critical for the assessment of future sea water intrusion in response to sea level rise, Hydrol. Earth Syst. Sci., 16, 1845-1862, doi:10.5194/hess-161845-2012, 2012.

Jupiter: The Danish National Well Database, available online: http: //www.geus.dk, last access: July 2011.

Kirkegaard, C., Sonnenborg, T. O., Auken, E., and Jorgensen, F.: Salinity Distribution in Heterogeneous Coastal Aquifers Mapped by Airborne Electromagnetics, Vadose Zone J., 10, 125-135, 2011.

Kuijpers, A.: Råstofgeologiske undersøgelser i Østersøen: Gedser, område 560 (Geological investigations for raw materials in the Baltic Sea: Gedser, Area 560), Udført for Skov- og Naturstyrelsen, DGU Kunderapport nr. 21, Copenhagen, 1991.

LaBolle, E. M., Fogg, G. E., and Eweis, J. B.: Diffusive fractionation of $\mathrm{H}-3$ and $\mathrm{He}-3$ in groundwater and its impact on groundwater age estimates, Water Resour. Res., 42, W07202, doi:10.1029/2006WR005842, 2006.

Langevin, C. D., Thorne, D. T., Dausman, A. M., Sukop, M. C., and Guo, W.: SEAWAT Version 4: a computer program for simulation of multi-species solute and heat transport, US Geological Survey Techniques and Methods, Book 6, Chapter A22, US Geological Survey, Reston, VA, 2007.

Larsen, F., Sonnenborg, T. O., Madsen, P., Ulbak, K. A., and Klitten, K.: Saltvandsgrænsen i kalkmagasinerne i Nordøstsjælland, Delrapport 6. Saltvandsudvaskning i Danienkalk og Skrivekridt - Detailundersøgelser i Karlslunde værkstedsområde, Geological Survey of Denmark and Greenland, Copenhagen, 1-103, 2006.

Maurer, H., Friedel, S., and and Jaeggi, D.: Characterization of a coastal aquifer using seismic and geoelectric borehole methods, Near Surf. Geophys., 7, 353-366, 2009. 
Misut, P. E. and Voss, C. I.: Freshwater-saltwater transition zone movement during aquifer storage and recovery cycles in Brooklyn and Queens, New York City, USA, J. Hydrol., 337, 87-103, 2007.

Pool, M. and Carrera, J.: Dynamics of negative hydraulic barriers to prevent seawater intrusion, Hydrogeol. J., 18, 95-105, 2010.

Post, V.: Fresh and saline groundwater interaction in coastal aquifers: Is our technology ready for the problems ahead?, Hydrogeol. J., 13, 120-123, 2005.

Rumbaugh, J. O. and Rumbaugh, D. B.: Guide to Using Groundwater Vistas, Version 6, Environmental Simulations, Inc., Reinholds, Pennsylvania, USA, 2011.

Sørensen, K. I. and Auken, E.: SkyTEM: a new high-resolution helicopter transient electromagnetic system, Explor. Geophys., 35, 191-199, 2004.

Sonnenborg, T., Christensen, B., Nyegaard, P., Henriksen, H., and Refsgaard, J.: Transient modeling of regional groundwater flow using parameter estimates from steady-nchexstate automatic calibration, J. Hydrol., 273, 188-204, 2003.

Sueltenfuss, J., Roether, W., and Rhein, M.: The Bremen mass spectrometric facility for the measurement of helium isotopes, neon, and tritium in water, Isotopes Environ. Health Stud., 45, 83-95, 2009.

Sueltenfuss, J., Purtschert, R., and Fuehrboeter, J. F.: Age structure and recharge conditions of a coastal aquifer (northern Germany) investigated with ${ }^{39} \mathrm{Ar},{ }^{14} \mathrm{C},{ }^{3} \mathrm{H}$, He isotopes and $\mathrm{Ne}$, Hydrogeol. J., 19, 221-236, 2011.

Sulzbacher, H., Wiederhold, H., Siemon, B., Grinat, M., Igel, J., Burschil, T., Günther, T., and Hinsby, K.: Numerical modelling of climate change impacts on freshwater lenses on the North Sea Island of Borkum using hydrological and geophysical methods, Hydrol. Earth Syst. Sci., 16, 3621-3643, doi:10.5194/hess-163621-2012, 2012.

Tang, H. W., Lei, Y., Lin, B., Zhou, Y. L., and Gu, Z. H.: Artificial intelligence model for water resources management, Proc. Inst. Civil. Eng. Water Manag., 163, 175-187, 2010.

Tran, L. T., Larsen, F., Pham, N. Q., Christiansen, A. V., Tran, N., Vu, H. V., Tran, L. V., Hoang, H. V., and Hinsby, K.: Origin and extent of fresh groundwater, salty paleowaters and recent saltwater intrusions in Red River flood plain aquifers, Vietnam, Hydrogeol. J., 20, 1295-1313, doi:10.1007/s10040-012-0874-y, 2012.
Troldborg, L., Jensen, K. H., Engesgaard, P., Refsgaard, J. C., and Hinsby, K.: Using Environmental Tracers in Modeling Flow in a Complex Shallow Aquifer System RID G-5274-2011, J. Hydrol. Eng., 13, 1037-1048, 2008.

Vandenbohede, A., Luyten, K., and Lebbe, L.: Effects of global change on heterogeneous coastal aquifers: A case study in Belgium, J. Coast. Res., 24, 160-170, 2008.

Vandenbohede, A., Hinsby, K., Courtens, C., and Lebbe, L.: Flow and transport model of a polder area in the Belgian coastal plain: example of data integration, Hydrogeol. J., 19, 1599-1615, 2011.

van Roosmalen, L., Christensen, B. S. B., and Sonnenborg, T. O.: Regional differences in climate change impacts on groundwater and stream discharge in Denmark, Vadose Zone J., 6, 554-571, 2007.

Viezzoli, A., Christiansen, A. V., Auken, E., and Sorensen, K.: Quasi-3D modeling of airborne TEM data by spatially constrained inversion, Geophysics, 73, F105-F113, doi:10.1190/1.2895521, 2008.

Webb, M. D. and Howard, K. W. F.: Modeling the Transient Response of Saline Intrusion to Rising Sea-Levels, Ground Water, 49, 560-569, 2011.

Werner, A. D. and Simmons, C. T.: Impact of Sea-Level Rise on Sea Water Intrusion in Coastal Aquifers, Ground Water, 47, 197-204, 2009.

Zheng, C.: MT3DMS v5.3 - a modular three-dimensional multispecies transport model for simulation of advection, dispersion and chemical reactions of contaminants in groundwater systems. Supplemental User's Guide, Technical Report, The University of Alabama, 2010.

Zheng, C. and Wang, P. P.: MT3DMS, a modular three-dimensional multispecies model for simulation of advection, dispersion and chemical reactions of contaminants in groundwater systems: documentation and User's Guide, US Army Engineer Research and Development Center Contract Report SERDP-99-1, USAERDC, Vicksburg, MI, 1999. 